\title{
Pediatric and neonatal extracorporeal life support: current state and continuing evolution
}

\author{
Brian P. Fallon ${ }^{1} \cdot$ Samir K. Gadepalli ${ }^{2} \cdot$ Ronald B. Hirschl ${ }^{2}$ \\ Accepted: 26 November 2020 / Published online: 1 January 2021 \\ (c) The Author(s), under exclusive licence to Springer-Verlag GmbH, DE part of Springer Nature 2021
}

\begin{abstract}
The use of extracorporeal life support (ECLS) for the pediatric and neonatal population continues to grow. At the same time, there have been dramatic improvements in the technology and safety of ECLS that have broadened the scope of its application. This article will review the evolving landscape of ECLS, including its expanding indications and shrinking contraindications. It will also describe traditional and hybrid cannulation strategies as well as changes in circuit components such as servo regulation, non-thrombogenic surfaces, and paracorporeal lung-assist devices. Finally, it will outline the modern approach to managing a patient on ECLS, including anticoagulation, sedation, rehabilitation, nutrition, and staffing.
\end{abstract}

Keywords Extracorporeal membrane oxygenation (ECMO) $\cdot$ Extracorporeal life support (ECLS) $\cdot$ Pediatric $\cdot$ Neonatal · Respiratory failure

\section{Introduction}

Extracorporeal life support (ECLS) provides life-sustaining gas exchange and hemodynamic support for patients with acute pulmonary or cardiac failure. Pioneered in neonatal patients [1], ECLS has expanded exponentially to routine use in pediatric and adult patients. ECLS has been defined by the following characteristics:

1. Supportive: ECLS is not a curative treatment. ECLS is often initiated when patients fail optimal treatment for their underlying condition. It sustains the life of the patient by maintaining adequate hemodynamics and gas exchange while they continue further treatment with the goal of organ recovery or as a bridge to organ replacement.

2. Temporary: ECLS does not serve as destination therapy. It provides temporary support to those patients whose underlying condition is reversible or who are candidates

Brian P. Fallon

bfallon@med.umich.edu

1 Department of Surgery, ECLS Laboratory, B560 MSRB II/ SPC 5686, Michigan Medicine, University of Michigan, 1150 W. Medical Center Drive, Ann Arbor, MI 48109, USA

2 Department of Surgery, Section of Pediatric Surgery, University of Michigan, Ann Arbor, MI, USA for organ replacement or transplantation. The duration of "temporary" varies widely, with patients having survived courses of ECLS for $>1$ year.

3. Partial or total: patients can receive both hemodynamic and gas-exchange support with veno-arterial (V-A) ECLS or gas-exchange support alone with veno-venous $(\mathrm{V}-\mathrm{V})$ ECLS. Additionally, ECLS can be titrated to offer varying levels of support according to each patient's needs.

4. Avoids iatrogenic injury: patients with pulmonary failure often sustain considerable lung injury from highpressure mechanical ventilation. Likewise, vasopressor use, particularly at high doses, can cause ischemic injury to the large and small intestine, kidneys, and extremities. ECLS can replace the gas-exchange function of the lungs and promote lung recovery on lower ventilator settings and provide hemodynamic support to allow for the weaning of vasopressors and restoration of adequate perfusion.

In this review, we discuss the evolution and potential for future developments in the standard of care for ECLS, inclusive of (1) indications and contraindications, (2) approaches to cannulation, (3) equipment, and (4) management. 


\section{Indications and contraindications}

\section{Indications}

ECLS is indicated for children with respiratory failure refractory to ventilator management (Table 1). One metric commonly used to define respiratory failure-often in neonates-is the oxygenation index (OI). This is calculated as $\mathrm{MAP} \times \mathrm{FiO}_{2} \times 100 / \mathrm{PaO}_{2}$ (post-ductal), where MAP is the mean airway pressure, $\mathrm{FiO}_{2}$ is the fraction of inspired oxygen, and $\mathrm{PaO}_{2}$ is the arterial partial pressure of oxygen. An OI of 25 is associated with a $50 \%$ mortality, whereas OI of 40 is associated with an $80 \%$ mortality. Traditionally, neonates were candidates for ECLS when OI reached 40; however, as the safety of ECLS has improved, ECLS is commonly considered for neonates with OI over 25 and strongly indicated for OI 40 or over. Special consideration must be given to those patients that are on modes of ventilation other than conventional ventilator support (e.g. high-frequency jet ventilation, high-frequency oscillator ventilation) since the relationship between OI and survival is altered [2, 3]. Another metric commonly used to stratify respiratory failure in pediatric and adult patients is $\mathrm{PaO}_{2}$ to $\mathrm{FiO}_{2}(\mathrm{P}: \mathrm{F})$ ratio. Many centers consider ECLS for a $\mathrm{P}: \mathrm{F}$ ratio less than 100 , though others use stricter criteria of $P: F$ ratio less than 60-80. Hypercapneic respiratory failure (with $\mathrm{pH}$ persistently less than 7.0-7.25) may also be the primary indication for ECMO, for example in the setting of refractory asthma $[4,5]$.

Septic shock has long been an indication for ECLS with good outcomes in neonates [6]. Very early data on ECLS use for the management of septic shock in pediatric patients were promising, albeit in small numbers [7-9]. Subsequent studies demonstrated opposing results [10, 11]. Perhaps because of these later studies combined with the theoretical

Table 1 Neonatal and pediatric ECLS indications

\begin{tabular}{ll}
\hline Indications & Contraindications \\
\hline $\begin{array}{l}\text { Oxygenation index }>40 \\
\mathrm{PaO}_{2} \text { to } \mathrm{FiO}_{2} \text { ratio }<60\end{array}$ & $\begin{array}{c}\text { Lethal chromosomal or other anomaly } \\
\text { Poor predicted neurologic outcome, } \\
\text { irreversible brain injury }\end{array}$ \\
$\mathrm{pH}<7.25$ & Uncontrolled bleeding \\
Shock & ICH $\geq$ Grade III \\
$\mathrm{A}-\mathrm{aDO}_{2}>500 \mathrm{mmHg}$ & Advanced multi-organ system failure \\
$P_{\text {plat }}>30 \mathrm{~cm} \mathrm{H} \mathrm{O}$ & Ventilation $>14$ days \\
& Weight $<1-1.5$ kg \\
& EGA $<30$ weeks
\end{tabular}

$\mathrm{PaO}_{2}$ arterial partial pressure of oxygen, $\mathrm{FiO}_{2}$ fraction of inspired oxygen, A- $a \mathrm{DO}_{2}$ alveolar-arterial oxygen gradient, Pplat plateau pressure, ICH intracranial hemorrhage, EGA estimated gestational age risk of circuit contamination, there has been a slow adoption of ECLS for sepsis, particularly in pediatric patients. However, the two largest series to date (45 and 21 children) provide strong support for the use of ECLS for septic shock. In children with severe multi-organ failure (94\% had failure of at least three organ systems), survival was 47 and $43 \%$, respectively $[12,13]$. Furthermore, one group achieved survival of $78 \%$ when using central cannulation for pediatric patients with septic shock, thought to be due to the higher flow rates afforded by central cannulation resulting in more rapid resolution of shock [14]. Another series of 80 patients achieved a survival rate of $55 \%$. Of note, $71 \%$ of those patients underwent central cannulation, which was associated with significantly improved survival [15]. This study suggested that ECLS likely provides a survival benefit to a pediatric patient with septic shock whose predicted mortality exceeds $47 \%$. Taken together, these recent series provide robust evidence in support of ECLS use for patients with refractory septic shock. The American College of Critical Care Medicine has recommended ECLS for pediatric septic shock refractory to fluids, vasopressors, and inotropes [16].

Pediatric lung transplant is performed only about 100 times per year, of which approximately $5 \%$ require ECLS support as a bridge to transplant [17]. Data in adults demonstrate improved outcomes with the use of V-V ECLS pretransplant [17]. Early reports demonstrated poor outcomes associated with ECLS use prior to lung transplant [17-19], but a recent large series found that outcomes for patients supported by ECLS prior to lung transplant were comparable to patients not requiring ECLS [20]. Pediatric lung transplants have been successfully performed on ECLS in rare cases [21]. Though many cannulation techniques have been used pre-transplant, cervical cannulation with a doublelumen cannula and a compact circuit allow for mobility and prehabilitation prior to transplant [20, 22-24]. ECLS can also be continued post-operatively in the event of primary graft dysfunction $[22,25]$.

\section{Contraindications}

ECLS is a temporary therapy; it does not treat a patient's underlying pathology. Rather, it provides the patient with adequate gas exchange and hemodynamic support as a bridge to organ recovery or transplant. It follows, then, that ECLS does not have a role in the management of any patient for whom there is no expectation of recovery from organ failure. The other subset of patients for whom ECLS is contraindicated are those who stand to suffer more harm than benefit from extracorporeal circulation. These patients are primarily those who have recent or active bleedingspecifically intracranial bleeding - such that the addition of the requisite systemic anticoagulation would make that risk 
prohibitively high. The risk-benefit balance in these cases has a significant subjective component and should be considered on a case-by-case basis.

Continual advances in ECLS technology and management strategies have challenged many of the traditional contraindications for ECLS. Estimated gestational age (EGA) of at least 34 weeks has typically been the cutoff for consideration of ECLS due to increased risk of intracranial hemorrhage and overall mortality [26-29]. A review of 752 ECLS runs in neonates with EGA 29-34 weeks in the ELSO registry found that survival was lower in the neonates with EGA 29-33 weeks (48\%) than neonates with EGA 34 weeks $(58 \%, \mathrm{p}=0.05)$, but there was no difference in ICH rates (21 vs. 17\%) [26]. This mortality difference is modest and may be clinically acceptable in select circumstances. Centers are now commonly considering patients with $\geq 30$ weeks EGA to carry an acceptable risk profile [30].

Another traditional cutoff has been a weight of $2 \mathrm{~kg}$. In neonates weighing below $2 \mathrm{~kg}$, it can be technically challenging to place cannulae large enough to provide adequate ECLS flow. Early data suggested that survival was significantly decreased in infants weighing less than $2 \mathrm{~kg}$ [27]. Though later data began to demonstrate improved survival, $2 \mathrm{~kg}$ remained a strong relative cutoff at most centers. Using data from the ELSO Registry from 1991 to 2002, Rozmiarek et al. estimated that infants weighing as little as $1.6 \mathrm{~kg}$ could be supported with an expected survival of over $40 \%$, though the model did not account for technical challenges of cannulation [31]. Cuevas Guamán et al. reported on 3 premature neonates $(31,32$, and 36 weeks EGA) with $\mathrm{CDH}$ weighing less than $2 \mathrm{~kg}(1.5,1.6$, and $1.8 \mathrm{~kg})$ who were offered ECLS using $8 \mathrm{Fr}$ arterial and venous cannulae. All 3 survived with good functional outcomes at 2 years of age [32]. Our University of Michigan experience includes cannulation of 5 neonates weighing less than $2 \mathrm{~kg}$. All 5 survived. With the advent of more efficient, smaller cannulae, the size cutoff has decreased to as low as $1 \mathrm{~kg}$ at some centers [30].

Neonates with high-grade ICH are at high risk of extension when subject to the systemic anticoagulation and hemodynamic changes associated with ECLS; however, grade 1 and $2 \mathrm{ICH}$ may not share this same risk. One group found that only $9 \%$ of infants with grade $1 \mathrm{ICH}$ diagnosed on preECLS head ultrasound experienced evolution of their ICH; half of these (4.5\% of the total) evolved to grade 3-4 [33]. The use of a cephalic venous drainage cannula and reduced anticoagulation in neonates on ECLS have been shown to diminish the risk of development of a new ICH and evolution of existing ICH [34].

Patients who are candidates for ECLS typically require high ventilator settings. While this aggressive mechanical ventilation is necessary to support gas exchange, it has also been associated with ventilator-induced lung injury, which can augment chronic lung disease [35] and increase mortality [36]. For this reason, extended periods of mechanical ventilation have been considered a contraindication for ECLS. An early study showed that a period of mechanical ventilation for 7 or more days prior to ECLS was been associated with worse survival as well as an increased risk of BPD [37]. More recent studies have suggested that pediatric patients supported by mechanical ventilation up to 14 days prior to ECLS cannulation have similar survival rates to those patients on the ventilator for fewer than 7 days prior to cannulation. Survival rates decrease when pre-ECLS mechanical ventilation exceeds 14 days $[38,39]$.

Cardiac arrest requiring CPR has been considered by many to be a contraindication to ECLS, as pre-ECLS CPR has been associated with worse outcomes [39]. However, many centers now consider patients who suffer pre-ECLS cardiac arrest candidates for support. In recent years, ECLS to support CPR (ECPR) has made up 11\% of neonatal and $22 \%$ of pediatric ECLS cases, with survival rates of $67 \%$ and 56\% respectively [40]. A major concern with ECPR is that cerebral hypoxia from cardiac arrest would result in poor neurologic outcomes for these patients regardless of subsequent adequate perfusion from ECLS; however, this has not been the case. A single-center review of pediatric patients undergoing ECPR found that $84 \%$ of the patients who survived to discharge had favorable neurological outcomes [41]. A second center demonstrated similar success in a group of pediatric patients: $73 \%$ survived to discharge, $75 \%$ of whom had no change in their pediatric cerebral performance category (PCPC) scores [42].

\section{Artificial placenta}

Research on an artificial placenta dates back to the earliest days of ECLS research [43]. The placenta was perhaps a likely starting point, as it naturally provides extracorporeal circulation to the developing human fetus. Since that time, remarkable progress has been made. There are currently multiple groups working to develop an artificial placenta system in the lab using premature lamb models. Though each system is unique, they share a few defining characteristics: specific design for extremely low gestational age newborns (ELGANs), maintenance of fetal circulation, fluidfilled lungs, and cannulation of the umbilical vein and/or artery. One approach uses the umbilical artery drainage and umbilical vein reinfusion for pumpless arterio-venous (A-V) ECLS, with the fetus submerged in an artificial womb [44, 45]. Given its exclusive use of the umbilical vessels, the A-V approach would require delivery of the fetus for direct cannulation. The other approach uses internal jugular vein drainage and umbilical vein reinfusion for pump-driven V-V ECLS and maintains the fetus in a typical neonatal ICU incubator (Fig. 1). This system could be applied after birth to infants failing maximal medical therapy or preemptively 


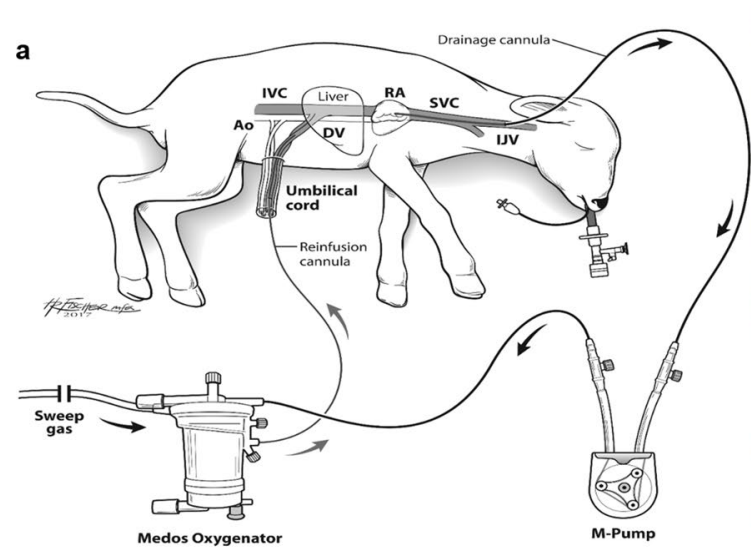

Fig. 1 a Schematic of the artificial placenta with V-V ECLS configuration; b Photo of an extremely premature sheep supported by the V-V ECLS artificial placenta. Ao: aorta; DV: ductus venosus; IJV: internal jugular vein; IVC: inferior vena cava; RA: right atrium; SVC:

after proper risk stratification. Many systems in development have been shown to provide adequate respiratory support for a developing fetus and promote largely normal development of lungs [44, 46, 47], brain [48, 49], spleen [50], and intestine [51, 52]. Early efforts at miniaturization of the circuit to support animals weighing 500-800 g-comparable in size but more physiologically premature than ELGANshave been promising but require further refinement $[53,54]$. Given these significant advances, clinical translation may be on the horizon; however, significant hurdles remain, including the consistent recovery of animals after long-term artificial placenta support, reliable cannulation of $500 \mathrm{~g}$ animals with adequate support, infrastructure development within hospitals, and patient risk stratification.

\section{ECLS for COVID-19}

The COVID-19 global pandemic of respiratory infections caused by severe acute respiratory syndrome coronavirus-2 (SARS-CoV-2) has taken over 1 million lives [55]. Pediatric patients have been disproportionately spared from the infection. Children are estimated to make up $1-5 \%$ of diagnosed cases [56]. Though children do develop a fever and respiratory symptoms, severe pneumonia requiring critical care typically occurs in under $5 \%$ of diagnosed children and deaths are rare [57-62]. ECLS has been used to rescue adult patients with refractory respiratory failure due to COVID19. Early studies of ECLS use for SARS-CoV-2 infection in adults demonstrated poor outcomes in a small number of patients [63], creating doubt about the role of ECLS in this pandemic. A more recent report from the ELSO Registry of 1035 patients over 16 years old with confirmed COVID19 supported by ECLS found a $37 \%$ mortality rate, similar to mortality rates in adults supported by ECLS for other

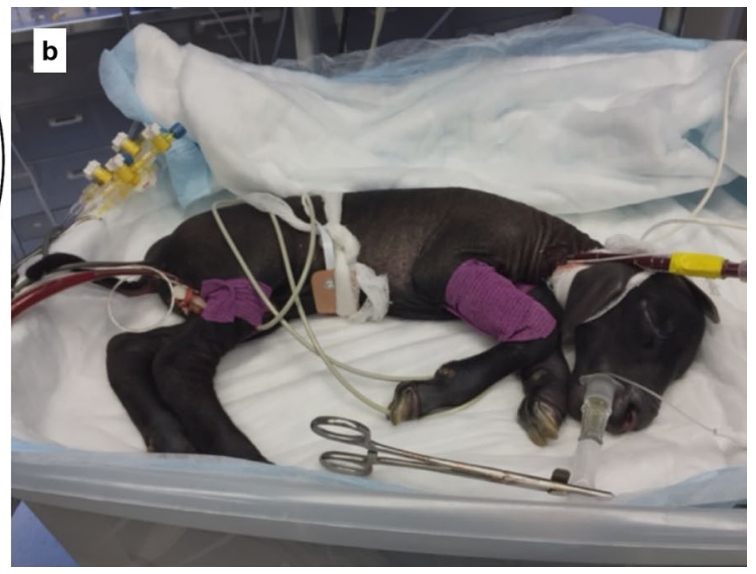

superior vena cava. a Reproduced with permission from Church et al. [46] (License number 4930520731885). b Original unpublished image

causes of respiratory failure [64]. Reports of ECLS use for children with COVID-19 are scarce. The largest case series of ECLS use in children diagnosed with SARS-CoV-2 infection included 7 patients from 4 European countries aged 54 days to 16 years [65]. Indications for ECLS were hypoxia, multisystem inflammatory syndrome in children (MIS-C), and septic shock from Staphylococcus aureus. Six initially required V-A ECLS, 3 of whom were subsequently converted to V-V ECLS due to cardiac recovery or differential hypoxemia. Three patients developed thrombotic complications (ischemic stroke, right atrial thrombus, and pulmonary embolism) despite therapeutic anticoagulation, commonly seen in adult patients with SARS-CoV-2 infection. Four of 7 patients survived to discharge. Oualha, et. al. published a series of 27 children admitted to a single pediatric ICU with a diagnosis of COVID-19 through April 20, 2020, that included 1 patient who required ECLS-a 6-year-old girl with no comorbidities who had uncomplicated varicella 14 days before admission. She developed multiorgan failure with $S$. aureus pneumonia and bacteremia and ultimately suffered a fatal intracranial hemorrhage [66]. In another series of 48 patients with COVID-19 who were admitted to 46 North American pediatric ICUs through April 3, 2020, 1 patient with significant underlying cardiomyopathy required $\mathrm{V}-\mathrm{A}$ ECLS for cardiogenic shock and was continuing therapy at the time of publication [62].

Emerging evidence suggests that children previously diagnosed with COVID-19 are susceptible to MIS-C (formerly called pediatric inflammatory multisystem syndrome temporally associated with SARS-CoV-2 [PIMS-TS]) [67]. Patients with MIS-C typically present very ill, with evidence of severe inflammation in multiple organ systems, commonly with cardiac involvement, as evidenced by the 3 patients with MIS-C in the series by Di Nardo, all of whom 
presented with cardiac injury requiring V-A ECLS [65]. Whittaker et al. [68] published a series of 58 patients diagnosed with MIS-C. Half of these patients developed shock requiring vasopressors. Three patients required ECLS for severe myocardial dysfunction, the outcomes of which were not reported. Kaushik et al. [69] published the experience of three New York City children's hospitals with 33 patients with MIS-C, including a 5-year-old patient who presented with severely depressed left ventricular function requiring V-A ECLS but ultimately suffering a fatal ischemic stroke. These data suggest that ECLS may be used in children with respiratory or cardiac failure associated with COVID-19 or MIS-C; however, more data are required prior to determining the true efficacy and role of ECLS in these patients.

\section{Evolving cannulation strategies}

ELSO has published a nomenclature that can help distinguish cannulation configurations, which provide information about the underlying physiology and the overall function of the ECLS circuit. The hyphen indicates the membrane lung, the letters to the left of the hyphen indicate drainage and to the right of the hyphen indicates return, the letters directly on either side of the hyphen are the original cannulae, and additional cannulae are placed outside these two letters on the appropriate side [70].

\section{Traditional cannulation strategies}

The earliest series of neonates supported with ECLS involved V-A cannulation-typically in the carotid artery and the internal jugular vein [71, 72] (Fig. 2). This remains the most common cannulation technique for pediatric and neonatal ECLS for non-cardiac indications [73]. V-A cannulation provides many benefits. First, it is typically a straightforward procedure from a technical standpoint. Second, given its historical predominance, surgeons across institutions have a large amount of experience with the technique. Thirdly, the arterial reinfusion provides hemodynamic support, which can rapidly stabilize an infant who is clinically deteriorating. Fourth, the positioning of the reinfusion cannula typically allows for stable high flows with no recirculation. Finally, by draining from the right atrium and reinfusing distal to the aortic valve, the blood flow through right heart is significantly decreased, allowing for cardiac rest and recovery, which is particularly beneficial for patients with pulmonary hypertension, such as those with congenital diaphragmatic hernia and persistent pulmonary hypertension of the newborn. A major concern with V-A cannulation is the hypothetical stroke risk associated with ligation of the carotid artery and reinfusion of blood from the ECLS circuit into the systemic circulation. A large study of the ELSO Registry found that, while overall stroke risk was higher with carotid artery cannulation (5.2 vs. 3.7\%), this difference disappeared after adjusting for factors such as age, support type, and underlying disease process [74]. An additional study of patients undergoing ECPR support found no association between the site of peripheral cannulation (i.e., carotid vs. femoral artery) and neurological injury [75]. This suggests that carotid artery cannulation may be safer than commonly thought. V-A ECLS also causes a decrease in coronary artery flow [76] and increases left ventricular end diastolic pressure (i.e., afterload), which can decrease cardiac output, increase the risk of pulmonary edema, and potentially hinder cardiac recovery [77-79].

An alternative to $\mathrm{V}-\mathrm{A}$ cannulation is $\mathrm{V}-\mathrm{V}$ cannulation with either a double-lumen cannula or, less commonly, two single-lumen cannulae [80]. Double-lumen cannulae are most commonly placed in the internal jugular vein, though they can be placed in the femoral vein in adults and larger pediatric patients. Both drainage and reinfusion occur in or very near to the right atrium, which produces recirculation-a major disadvantage of V-V ECLS [81]. The effects of recirculation can be minimal or profoundly negative, depending on the patient's volume status, their cardiac output, and the position of the cannula [81]. Additionally, V-V provides no hemodynamic support, as reinfusion occurs in the low-pressure right atrium and passes through the pulmonary circulation before entering the systemic circulation. Despite the lack of hemodynamic benefit, there are many advantages to V-V cannulation. First, double-lumen cannulae allow for single-vessel access that can be achieved percutaneously, thus limiting the morbidity of the cannulation procedure and preserving the patient's carotid artery, though double-lumen cannula placement tends to be avoided in neonates and infants due to a high rate of complications such as right atrial perforation [82]. Second, oxygenated blood is delivered to the pulmonary vasculature, which has been shown to decrease pulmonary artery resistance and reduce the potential complications associated with emboli from the ECLS circuit [83, 84]. Third, V-V ECLS increases coronary artery blood flow [85] and oxygen delivery [86] by increasing the oxygen saturation of native cardiac output, which is the primary source of coronary artery perfusion. Lastly, it avoids the increase in left ventricular afterload that is seen with V-A ECLS [81].

\section{Femoral cannulation}

Femoral cannulation is commonly used in adults and can be an option for older pediatric patients. Before 5 years of age, the femoral vessels are typically too small to accept a cannula that can provide adequate venous drainage. For that reason, femoral cannulation is avoided in patients younger than 5 years old, although cannulation of the iliac vein is an 

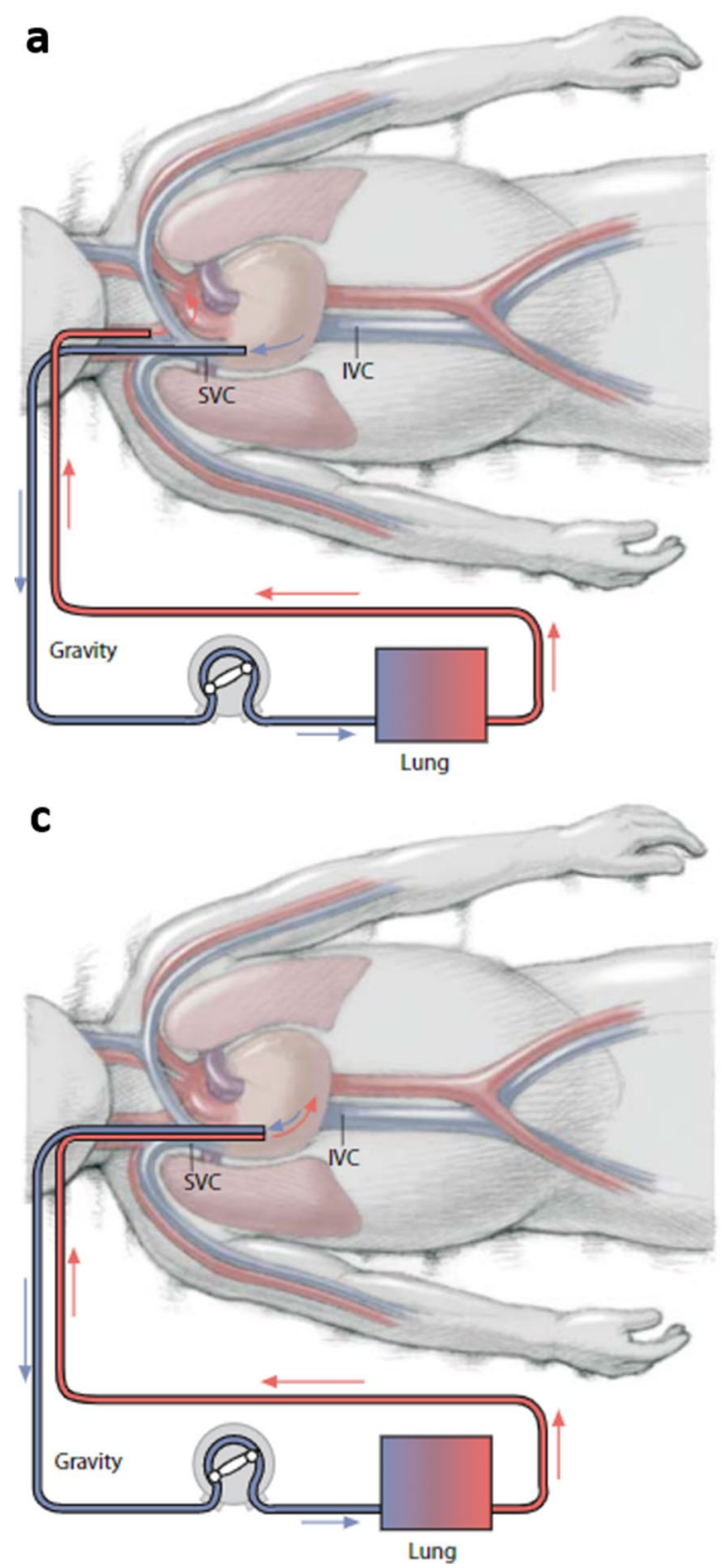

Fig. 2 a In veno-arterial ( $\mathrm{V}-\mathrm{A})$ cannulation, drainage is from the superior vena cava (SVC) and right atrium (RA) via the right internal jugular vein (IJ) and reinfusion is to the right carotid artery (CA); b In veno-venous $(\mathrm{V}-\mathrm{V})$ cannulation with two cannulae, drainage is from the SVC and RA via the right IJ and reinfusion is to the inferior

option [73, 80]. In V-V ECLS, the femoral vein can be used as drainage along with internal jugular reinfusion. With the safety of double-lumen cannulae that can be placed in the $\mathrm{IJ}$, this approach is used less commonly [80]. In V-A ECLS, both the femoral artery and vein can be used for access. While this technique has the benefit of sparing the carotid artery, it is associated with a rate of limb complications that can reach $50 \%$ in children [87]. A number of strategies to prevent limb ischemia have been attempted. One approach is

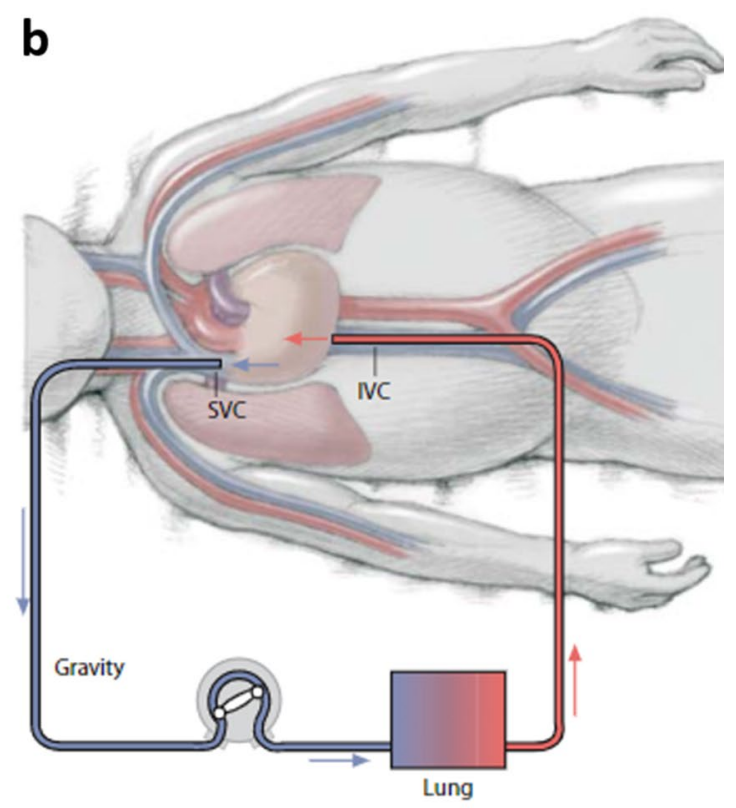

vena cava (IVC); $\mathbf{c}$ In V-V cannulation with a double-lumen cannula, drainage is from the SVC and IVC and reinfusion is into the RA. Reproduced with permission from Frischer et al. [176] (License number 4924341211861)

to insert a distal perfusion catheter into the superficial femoral artery just distal to the cannulation site for anterograde flow [88-90] or into the posterior tibial artery for retrograde flow [91]. Data are limited and inconclusive on the relative benefit of prophylactic versus reactive placement of a distal arterial perfusion catheter in the pediatric population [92]. A distal venous drainage catheter has also been described as a method to decrease tissue edema and further improve perfusion during long-term ECLS [88]. Close monitoring of limb 
perfusion in any patient with femoral cannulation is critical, regardless of the presence of a distal perfusion catheter, as limb ischemia can occur even after catheter placement [92, 93]. Alternatively, rather than inserting a distal catheter, a prosthetic graft can be sewn to the femoral artery and subsequently cannulated ("stovepipe" or "side-arm" cannulation) to prevent occlusion of the native vessel with the cannula [94]. Limited series demonstrates that this technique leads to adequate perfusion - including to the upper body — while avoiding limb ischemia altogether [94-96]. Stovepipe cannulation requires an open femoral artery cut-down, which is time-consuming, limiting its application in patients that are actively deteriorating; produces a risk of bleeding in the surgical bed; and introduces an additional infectious risk, as a short segment of graft is often left in the surgical bed after decannulation. The technique should be considered for select patients in whom femoral cannulation is being performed in a controlled setting.

\section{Indications for additional cannula placement (hybrid cannulation)}

Another risk of femoral cannulation is North-South Syndrome, in which the head and upper extremities are hypoperfused relative to the lower extremities. This has been referred to as "red legs, blue head", named for the physical appearance of the patient experiencing this condition. This occurs when a patient with cardiorespiratory failure on femoral V-A ECLS begins to recover cardiac function but lung function remains poor. Native cardiac output increases, but the blood ejected by the heart is relatively hypoxic and is preferentially distributed to the head, heart, and upper extremities while ECLS oxygen-rich blood flow from the femoral cannula only tends to perfuse as high as the distal aorta. One option for management of this condition is to add an additional venous reinfusion cannula into the internal jugular vein, thereby converting the circuit to veno-arteriovenous (V-AV) ECLS - that is, venous drainage with arterial and venous reinfusion. This continues the hemodynamic support of femoral V-A ECLS while providing additional oxygenated blood directly into the right atrium - as with $\mathrm{V}-\mathrm{V}$ ECLS-thereby increasing perfusion of oxygenated blood to the brain, coronary vessels, and upper extremities. This does not increase overall oxygen delivery of the ECLS circuit, but rather anatomically redistributes the perfusion. The relative flow into the jugular venous and femoral arterial reinfusion limbs can be controlled, allowing for close management of the relative redistribution of inflow [97].

A third cannula can also be beneficial for patients on V-V support who develop cardiac failure. In these patients, either a femoral or carotid cannula is placed to convert to venovenoarterial (V-VA) ECLS to provide hemodynamic support [98]. Use of an additional venous drainage cannula with
V-A ECLS (VV-A) can provide increased drainage - and thus flow-in obese patients, whose body surface area is disproportionately larger than their vessel size [99].

\section{Equipment}

\section{Simpler circuits}

The early years of ECLS were dominated by V-A cannulation requiring open cut-down. The current era of ECLS (roughly marked by the H1N1 flu pandemic of 2009) was sparked by the development of simpler and safer ECLS circuits. The development of magnetically levitated (MagLev) pumps has allowed the application of centrifugal pumps to long-term ECLS with associated safety (minimal application of high negative pressures and high positive pressures with occlusion of the inlet and outlet of the pump, respectively) over traditional roller pumps. As V-V ECLS gained acceptance, percutaneous techniques, and double-lumen cannulae simplified cannulation. The current generation of polymethyl pentene hollow-fiber oxygenators is smaller and more efficient with lower resistance and smaller priming volumes which is ideal for neonatal and pediatric patients [100, 101]. They are also less likely to fail, reducing the need for changing out circuit components [100]. All of these changes in technology, including centrifugal pumps with integrated batteries, are associated with more compact circuits, which also facilitate patient transport. The ECLS circuit can now be brought to an outside facility to stabilize a patient for transfer, rather than risking the transfer of an unstable patient to an ECLS center [102].

\section{Nonthrombogenic circuits}

The exposure of blood to the foreign surfaces of an ECLS circuit produces a significant inflammatory response in the patient. It triggers a complicated cellular and protein response to the circuit characterized by protein adsorption, activation of the coagulation pathway, platelet and leukocyte activation and adhesion, and triggering of the complement cascade [103]. The activation of pro-thrombotic pathways within the circuit drives the need for systemic anticoagulation to maintain circuit patency. Many attempts have been made at coating the surfaces of circuits to limit inflammation, prevent circuit clotting, and obviate the need for anticoagulation. Currently, many circuits are coated with heparin. This has been shown to limit the inflammatory response [104-106], but these circuits have not successfully replaced the need for systemic heparin [107]. One concern with heparin-coated circuits is the risk 
of heparin-induced thrombocytopenia (HIT). It is thought that modern heparin-coated circuits-with heparin covalently bonded to the surface-do not leach heparin and thus would not contribute to the risk of HIT; however, there are limited data available to evaluate this [108]. The other major circuit coating currently in clinical use is phosphorylcholine (PPC). It uses the zwitterionic component of the phospholipid bilayer of the cell membrane to passively prevent the adhesion of proteins and cells to the surface of the circuit [109]. Its use in the literature is primarily limited to cardiopulmonary bypass circuits, in which it has been shown to reduce inflammation [110, 111], postoperative bleeding, and heparin dosing [112]. Though many other approaches to non-thrombogenic circuit coatings are in development in the laboratory, one of the most promising is the use of coating materials that release nitric oxide (NO), mimicking the function of the native vascular endothelium. NO prevents platelet aggregation and adhesion and inhibits leukocyte activation. This effect lasts milliseconds, allowing for normal hemostatic function within the patient and making it an ideal model for local anticoagulation of ECLS circuits. Many NOreleasing compounds are currently in development, some of which have demonstrated efficacy for $4 \mathrm{~h}$ in a rabbit model of an arterio-venous shunt circuit [113, 114]. The addition of a direct thrombin inhibitor to the NO-releasing coating helps prevent fibrin deposition [115]. One limitation of NO-releasing materials is that only a limited number of NO donors can be incorporated into the coating, which may limit the duration of its non-thrombogenic effect. Studies have demonstrated continued NO flux for 7 and 11 days $[114,116]$ in a coated intravenous catheter in vivo. Another found sustained NO release after 125 days in phosphate-buffered solution [117], but the long-term NO release of these coatings has yet to be demonstrated in extracorporeal circuits. In addition to circuit coating, NO has also been blended into the circuit sweep gas to attenuate platelet consumption and activation within the membrane lung [118] and limit the inflammatory effect of cardiopulmonary bypass [119] as well as post-bypass ischemia-reperfusion injury [120].

\section{Servo regulation}

Automation will be a key component of the ECLS circuit of the future. Roller pumps rely on a siphon of venous blood driven by the vertical drop from the patient down to the pump (typically $100-150 \mathrm{~cm} \mathrm{H}_{2} \mathrm{O}$ ). If the siphon pressure drops (due to hypovolemia, pneumothorax, etc.) the pump will apply a negative pressure through the venous cannula on the right atrium. A pressure transducer-connected either directly to the circuit or to a small bladder-positioned at the lowest point of the circuit provides servo regulation to the pump, triggering it to slow or stop whenever it senses negative pressure [121]. Similar servo regulation can only be achieved with centrifugal pumps through the use of a bladder on the inlet side of the pump, which increases priming volume [121]. Servo regulation can also be used on the outlet side of the pump to slow the pump when pressures exceed a set threshold and on the sweep gas to ensure the sweep flow pressure does not exceed blood pressure within the oxygenator and produce an air embolus [122]. The circuits of the future will have the ability to regulate pump speed to achieve a set flow in a variety of patient conditions as well as to titrate pump speed and sweep flow to achieve target arterial blood gas values [123].

\section{Paracorporeal lung-assist devices}

Mobilization and physical therapy on ECLS has been shown to be associated with survival to lung transplantation [124] and a high rate of discharge home in adult patients [125]. Cervical cannulation with double-lumen cannulae has facilitated ambulation on ECLS. Continued compaction of circuits and circuit components will improve the safety and feasibility of ambulation on ECLS. Multiple groups are developing an integrated pump-lung device to maximally compact the ECLS circuit into a single wearable or, ideally, implantable device $[126,127]$. The one model specifically designed for children is the pediatric pump-lung (PediPL), implanted in the aorta and right atrium. It has been shown to provide the average blood flow of $1.14 \mathrm{~L} / \mathrm{min}$ and arterial oxygen saturation of $95 \%$ over 30 days [127]. In a model of respiratory failure, the PediPL provided respiratory stabilization over $4 \mathrm{~h}$ in a $\mathrm{V}-\mathrm{V}$ configuration [128].

For patients with adequate cardiac function and hemodynamic stability, a low-resistance, pumpless artificial lung may be the preferred method of long-term support. Such devices would be simpler and potentially cause less blood trauma than integrated pump-lungs. Typical cannulation would be direct to the pulmonary artery for inflow and to the left atrium for outflow, using the patient's right ventricle as the pump. While femoral cannulation has been used, central cannulation would facilitate ambulation and rehabilitation. An ideal population for this device would be children and adolescents with end-stage lung disease. These patients typically spend over 100 days on the transplant waiting list [129], which makes ECLS a poor option for routine management due to its cost and complexity. Artificial lungs could also be used as a bridge to recovery for patients with end-stage lung disease and primary or secondary pulmonary hypertension (e.g., BPD, lung hypoplasia from $\mathrm{CDH}$, fibrosis from pneumonia or ARDS). The artificial lung would not only provide gas-exchange support to these patients but also protection for the right ventricle from the continuously 
high afterload associated with pulmonary hypertension. The artificial lung would serve as an alternative low-resistance circuit, thus offloading the right ventricle and receiving preferential blood flow.

There are limited case reports of existing models of polymethyl pentene oxygenators being used as artificial lungs as bridges to transplant or recovery. One group out of Washington University in St. Louis has supported four children (ages 23 days to 2 years old) with the Quadrox iD or Novalung in a PA-to-LA configuration [130]. All patients had suprasystemic PA pressures before device implantation, which were reduced upon initiation of flow through the artificial lung. In fact, the majority of RV output flowed through the device rather than the native lungs. One child recovered after 23 days of support, one child underwent lung transplant

a

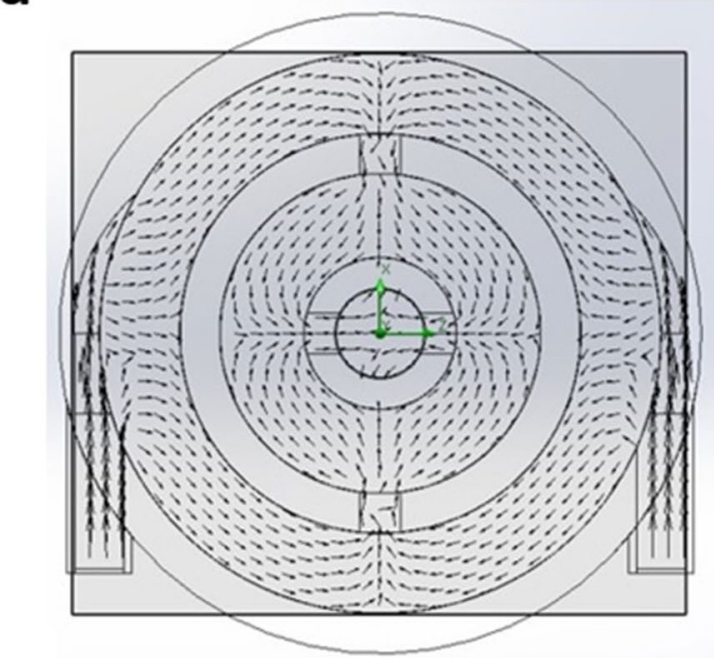

C

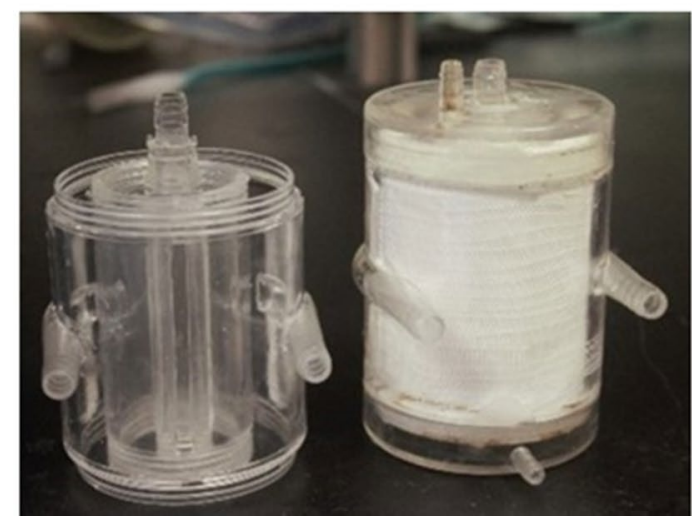

Fig. 3 The University of Michigan Pediatric MLung. a Computeraided design (CAD) drawing of pediatric MLung, top view. Arrows depict the blood flow pattern; b Top view of the pediatric MLung. Red lines depict the blood flow pattern. Solid yellow lines depict concentric gates. Key features of the MLung include: (1) Blood inlets; (2) outer fiber bundle; (3) inner fiber bundle; (4) blood outlet; c after 5 days of support, and two children were transitioned to comfort care due to severe intracranial hemorrhages after 54 and 74 days of support. The only other published pediatric case of artificial lung use involves a 15-year-old girl with pulmonary veno-occlusive disease and suprasystemic RV pressures who was supported for 30 days on the Novalung interventional lung assist (iLA) as a successful bridge to lung transplant [131].

While these cases of existing oxygenators demonstrate the feasibility of support with a pumpless artificial lung, current artificial lungs are not designed for this use. Multiple labs are developing gas exchange devices specifically designed as pumpless, low-resistance implants for pediatric patients with lung failure and pulmonary hypertension. The University of Michigan is developing the Pediatric MLung, which b

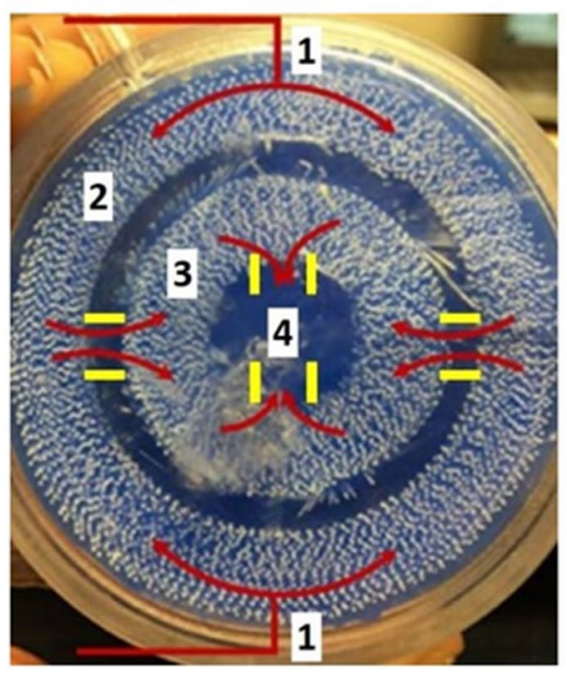

d

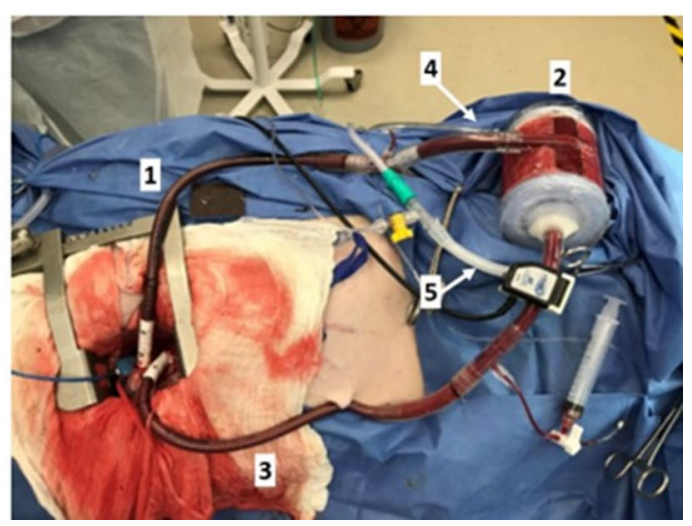

Pediatric MLung empty housing (left) and housing with fiber bundle installed (right); d. MLung in vivo immediately after cannulation and connection. Key features of the circuit include: (1) inlet cannula (from PA); (2) MLung; (3) outlet cannula (to LA); (4) sweep gas inlet; (5) gas outlet with suction tubing. b Reproduced with permission from Thompson et al. [132] (License number 4924370285770) 
is associated with a resistance less than half that of current commercially available oxygenators [132] (Fig. 3). A team at the University of Pittsburgh has successfully supported six sheep for 4-6 h with the Pittsburgh Pediatric Ambulatory Lung (P-PAL) with good gas exchange and flow rates and without significant hemolysis [133]. While progress is promising, such devices are not yet ready for clinical application.

\section{Patient management on ECLS}

\section{Anticoagulation and monitoring}

The current standard of care for anticoagulation for pediatric and neonatal ECLS is a continuous heparin infusion. It is well documented that heparin activity varies by age, though data to help understand this variation are lacking; therefore, dosing and monitoring protocols are largely institution-specific and guided by minimal evidence [134]. As antithrombin III (ATIII) is required for heparin to work as an anticoagulant, many institutions monitor and replace ATIII in children on ECLS. Some studies have found ATIII administration to be associated with increases in activated clotting time (ACT), ATIII activity, or anti-factor Xa (anti-Xa), but these have not demonstrated decreases in heparin infusions or improvements in clinical outcomes [135-137]. In fact, one study found an increase in the rate of circuit failure in patients receiving recombinant ATIII [136]. A recent multicenter, retrospective review of ATIII use in ECLS found that patients who received ATIII during ECLS had a higher rate of thrombotic and hemorrhagic events without a difference in mortality [138].

There is growing interest in direct thrombin inhibitors (e.g., bivalirudin, argatroban) as alternative anticoagulants to heparin. Direct thrombin inhibitors function independent of ATIII, so they theoretically could provide more stable anticoagulation than heparin. They also eliminate the risk of heparin-induced thrombocytopenia (HIT). The half-life of bivalirudin is about $25 \mathrm{~min}$, owing in part to its rapid cleaving by proteolytic enzymes. As a result of this short half-life (heparin 1-2 h), static blood-such as in a severely dilated atrium with poor drainage or a poorly ejecting ventricle-is at particularly higher risk of thrombosis than when on heparin; therefore, echocardiographic monitoring is recommended for such patients on bivalirudin with a transition to heparin if such thrombosis is found [139]. Additionally, argatroban is cleared by the liver and bivalirudin is partially renally cleared, so dose adjustments are necessary for hepatic and renal dysfunction, respectively.

At the current time, there is limited evidence comparing direct thrombin inhibitors to heparin. Sanfilippo et al. [140] performed a literature review on the use of bivalirudin in children on ECLS and found only four publications that included a total of 24 pediatric patients. Only one of these studies compared bivalirudin to heparin, observing that bivalirudin was associated with more stable coagulation profiles, lower blood loss, and administration of a smaller volume of platelets, fresh frozen plasma, and ATIII. The rate of thromboembolic events was similar between the groups [141]. These results were not analyzed separately in adults and children. In a more recent study, Hamzah et al. [142] retrospectively compared 16 pediatric patients on ECLS receiving bivalirudin with 16 receiving heparin and found fewer bleeding events and lower hospital costs in the bivalirudin group. There was no difference in the rate of thrombotic events. The largest series of pediatrics ECLS patients managed with bivalirudin found the direct thrombin inhibitor to be a feasible anticoagulation option for patients with a contraindication to heparin [143].

Argatroban is far more commonly used and available than bivalirudin, with $45 \%$ of respondents of an internal survey of ECLS centers responding that they can/do use argatroban versus 9\% citing use of bivalirudin [144]. Despite this, evidence for its use in pediatric and neonatal ECLS is limited to small case reports or case series, nearly all due to suspicion of HIT [145]. Kawada et al. [146] used argatroban as first-line anticoagulation for two neonatal patients on ECLS for 6 and 78 days with no hemorrhagic or thromboembolic events. Though direct thrombin inhibitors show promise, further trials are needed before they can be recommended as first-line anticoagulants for children on ECLS.

Monitoring of anticoagulation on ECLS is critical, as these patients walk a fine line between thrombosis and hemorrhage. The primary options for monitoring anticoagulation for children on ECLS receiving a systemic heparin infusion are ACT, activated partial thromboplastin time (aPTT), and anti-Xa, with thromboelastography (TEG) being less frequently used. ACT is the most commonly used monitoring test. Its benefits are that it is cheap, fast, and can be done at the bedside with very little blood. It measures the clotting of whole blood, which provides insight into the patient's overall coagulation status, rather than the heparin-specific effects. APTT measures the intrinsic coagulation pathway; as such it can identify other factor deficiencies in the presence of heparin using Heparinase which, therefore, allows a more specific assessment of the effect of heparin on the patient. Anti-Xa is the most specific of these tests, directly measuring the inhibition of clotting factor Xa by heparin-ATIII complexes. The use of these tests to guide the management of heparin anticoagulation varies widely across institutions, as there is no consensus on which test is most effective and practical. A recent meta-analysis comparing the use of ACT, aPTT, TEG and Anti-Xa to manage heparin anticoagulation in 
children on ECLS found that none of the tests correlated with thrombotic or hemorrhagic complications. Anti-Xa levels correlated more strongly with heparin dose than any of the other tests [147].

\section{Awake ECLS}

In the earliest days of ECLS, patients were continued on their pre-cannulation ventilator settings during ECLS support. Despite adequate gas-exchange support from ECLS, patient mortality was still high. Bartlett realized early success by turning down the ventilator and allowing the membrane lung to carry a larger burden of gas exchange while the native lungs rested [148], which has now become the standard approach [149]. Despite low ventilator settings, patients supported by ECLS may still require sedation to tolerate endotracheal intubation. However, sedation can delay the identification of strokes and put patients at risk of deconditioning and ventilator-associated pneumonia. Furthermore, extubation while on ECLS can minimize sedation requirements and promote rehabilitation and wakefulness. This approach has been called "awake ECLS". Its use has

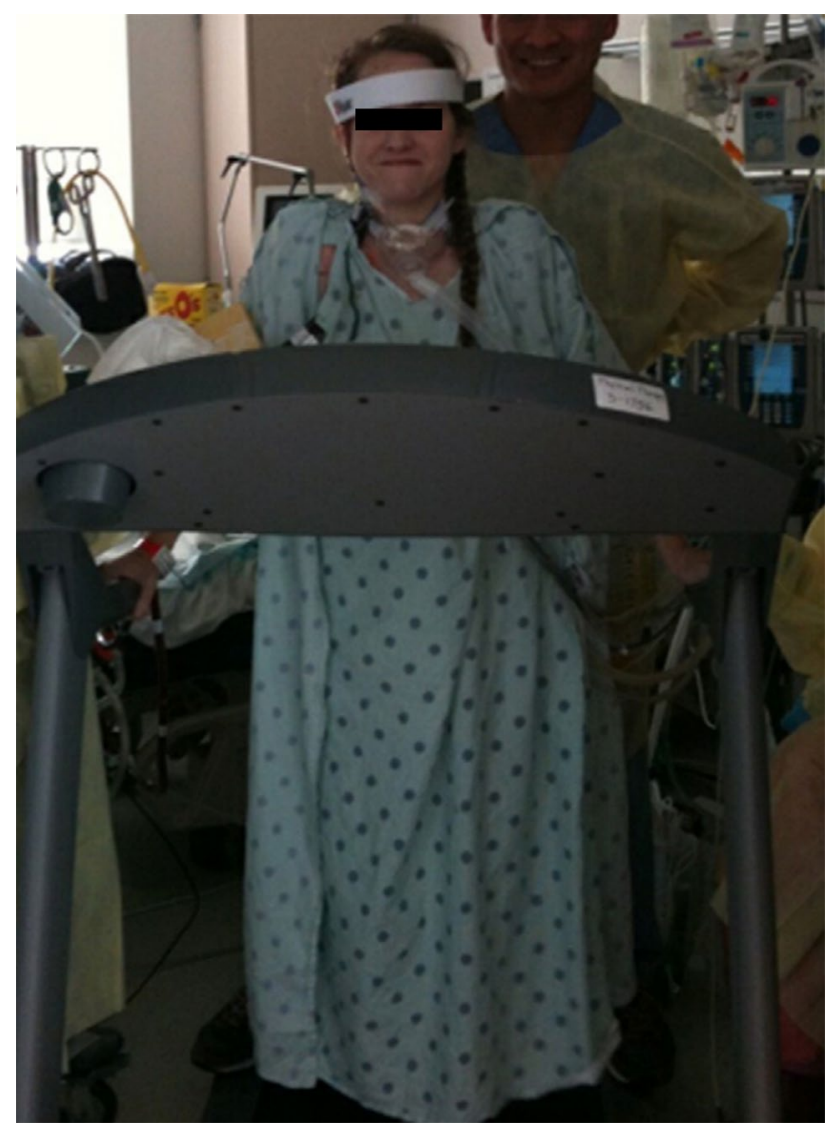

Fig. 4 Patient ambulating on a treadmill while on V-V ECLS. Reproduced with permission from Hayes et al. [25] (License number 4930510559332 grown among adult patients but reports in pediatric patients are limited [23-25, 150-152]. Recent series have demonstrated the feasibility of awake ECLS in pediatric patients as young as 2 days old as both a bridge to recovery and a bridge to transplant [153-155] (Fig. 4). Costa et al. noted a particular benefit of extubation for neonatal patients with persistent air leaks, avoiding positive pressure, and expediting the healing of the leak without the need for tube thoracostomy [155]. Cannulation for ECLS can also be done in an awake, non-intubated patient, which is a valuable approach to the management of impending respiratory failure due to airway obstruction [156, 157]. Alternatively, if a longer ECLS course or post-ECLS respiratory support is expected, a tracheostomy can be performed during ECLS support to achieve those same goals $[149,158]$.

\section{Prolonged ECLS}

In the early decades of ECLS, maximum acceptable run times were typically $<14$ days because it was considered that lung recovery would not occur beyond that time period. We have since come to realize that the lungs in fact can remodel and recover if support is provided for weeks to months on ECLS. A 7-year-old girl with $35 \%$ total body surface area full-thickness burns and severe inhalational lung injury amazingly recovered after support with ECLS for 605 days ( $>1.5$ years) [159]. Her story and other cases of prolonged ECLS with good outcomes highlight this potential for lung recovery months after the initial onset of lung disease and raise ethical issues around when ECLS is futile in patients with respiratory failure. A review of the ELSO Registry experience with 974 adult patients with respiratory failure from 1989 to 2013 with ECLS courses > 14 days and a median course of 21 days (range 14-208 days) demonstrated a survival of $45 \%$, which did not vary with ECMO duration [160]. Likewise, analysis of pediatric patients receiving ECLS for 21 or more days for respiratory indications demonstrated a 38\% survival [161]. Unlike with the adult experience, survival in these pediatric patients was inversely correlated with ECLS duration, although survival never decreased below $27 \%$ even in runs of over 6 weeks. It should be noted, however, that morbidity following prolonged ECLS courses is high: nearly all patients included in the study by Brogan et al. experienced at least one morbid complication, with $57 \%$ experiencing over 3 such complications [161]. Another series of 22 pediatric patients supported on ECLS for over 4 weeks found that 4 patients (19\%) survived to discharge, but 1 subsequently died and the 3 survivors were suffering from chronic lung disease (3), severe neuro-developmental delay (2), and renal failure (1) [162].

Patient heterogeneity and variable disease processes make it challenging to identify which patients will benefit from extending a course of ECLS and which patients have reached 
the point of futility. Interestingly, a 1995 study of 382 pediatric patients in the ELSO Registry found that ECLS support was electively terminated for the futility of pulmonary recovery or other reasons in $25 \%$ of all patients at a median ECLS duration of $282 \mathrm{~h}$ ( $~ 12$ days); however, simultaneously, $25 \%$ of all survivors had courses longer than 12 days, suggesting that $25 \%$ of those that were electively terminated may have survived [163]. Data on accurate predictive factors are limited. Brogan et al. found that acidosis and inotropic support were associated with mortality in prolonged ECLS courses, suggesting that continued hemodynamic instability despite full ECLS support portends a poor outcome [161]. Green found that peak ventilator inspiratory pressure and duration of intubation before ECLS, patient age, and the occurrence of several complications were all associated with mortality on ECLS [163]. The P-PREP [164], Ped-RESCUERS [165], and Neo-RESCUERS [166] tools have been developed to estimate the risk of mortality prior to the initiation of ECLS. Though both scoring systems are imperfect, they can serve as a starting point to inform important conversations with parents and family members.

\section{Nutrition}

Nutrition is a crucial aspect of the management of critically ill pediatric patients. This is equally true for patients on ECLS, as underweight status is an independent predictor of mortality for pediatric patients on ECLS [167]. Enteral nutrition for critically ill pediatric patients has been associated with numerous advantages compared to parenteral nutrition, including improved intestinal immunologic and absorptive function, reduced risk of hepatic injury, and reduced sepsisassociated complications [168]. However, as is the case with most critically ill patients, there is significant variation in nutritional management for ECLS patients. In a survey of 96 different centers providing neonatal or pediatric ECLS, Desmarais et al. found that $71 \%$ of centers typically provide enteral nutrition to patients on V-V ECLS, but that number dropped to 54\% for patients on V-A ECLS [169]. Reasons cited for avoiding enteral feeding included vasopressor use and certain diagnoses such as CDH. Though a number of studies exist in adults, the early pediatric literature was sparse. The 2010 ASPEN guidelines supported enteral feeding on ECLS, though they were based on limited data [168, 170]. A number of recent studies have provided stronger evidence in support of enteral feeding on ECLS. They have shown good success with routine enteral feeding despite inotrope support $[171,172]$ with potentially improved survival [172] and no major complications [171-173]. When combined with awake ECLS, neonatal patients can actually bottle feed to promote normal oral intake [155].

\section{Staffing models}

As ECLS continues to grow in its utilization and more centers gain experience and comfort with the technology, the clinical management of a patient on ECLS is evolving. Currently, patients supported by ECLS are in an ICU with both an ICU nurse and an ECLS specialist at the bedside full-time and a respiratory therapist is frequently present for ventilator management. This staffing model is resource-intensive and may not be sustainable as ECLS utilization grows. In the future, ECLS management-particularly for respiratory failure-may be as commonplace as management of ventilator or renal replacement therapy. With a moderate amount of additional training, ICU nurses can manage the ECLS circuit with the guidance of an ECLS specialist who is overseeing multiple patients, which has been demonstrated to save costs while having no detrimental effect on outcomes [174]. An additional model could be that of an ECLS step-down unit, in which a group of patients on ECLS are managed by a team of ICU nurses and ECLS specialists, allowing for a higher patient-to-staff ratio [175]. With continued progress in the simplification and safety of ECLS circuits, the intensive bedside management of these patients by multiple providers will no longer be necessary. Awake ECLS and wearable extracorporeal devices may even allow for the management of stable, long-term ECLS patients to be managed on the ward or at home, as has been achieved for patients with pacemakers, defibrillators, and ventricular assist devices.

Author contributions All authors contributed to the conceptualization of this review. The literature search and data analysis were performed by Brian Fallon. The work was drafted and critically reviewed by BF, $\mathrm{SG}$, and RH.

\section{Compliance with ethical standards}

Conflict of interest The authors declare that they have no conflict of interest.

\section{References}

1. Bartlett RH, Gazzaniga AB, Fong SW, Burns NE, Haiduc N, Medley TG, Wetmore N, Will D, Williams G, Woldanski C (1974) Prolonged extracorporeal cardiopulmonary support in man. J Thorac Cardiovasc Surg 68(6):918-932

2. Baumgart S, Hirschl RB, Butler SZ, Coburn CE, Spitzer AR (1992) Diagnosis-related criteria in the consideration of extracorporeal membrane oxygenation in neonates previously treated with high-frequency jet ventilation. Pediatrics 89(3):491-494

3. Smith DW, Frankel LR, Derish MT, Moody RR, Black LE 3rd, Chipps BE, Mathers LH (1993) High-frequency jet ventilation in children with the adult respiratory distress syndrome complicated 
by pulmonary barotrauma. Pediatr Pulmonol 15(5):279-286. https://doi.org/10.1002/ppul.1950150504

4. MacLaren G, Conrad S, Peek G (2015) Indications for pediatric respiratory extracorporeal life support. ELSO, Ann Arbor

5. Swaniker F, Kolla S, Moler F, Custer J, Grams R, Bartlett R, Hirschl R (2000) Extracorporeal life support outcome for 128 pediatric patients with respiratory failure. J Pediatr Surg 35(2):197-202. https://doi.org/10.1016/S0022-3468(00)90009-5

6. Bartlett RH (2007) Extracorporeal support for septic shock. Pediatr Crit Care Med 8(5):498-499. https://doi.org/10.1097/01. pcc.0000282163.60836.2c

7. McCune S, Short BL, Miller MK, Lotze A, Anderson KD (1990) Extracorporeal membrane oxygenation therapy in neonates with septic shock. J Pediatr Surg 25(5):479-482. https://doi. org/10.1016/0022-3468(90)90554-m

8. Beca J, Butt W (1994) Extracorporeal membrane oxygenation for refractory septic shock in children. Pediatrics 93(5):726

9. Goldman AP, Kerr SJ, Butt W, Marsh MJ, Murdoch IA, Paul T, Furnin RK, Tasker RC, Macrae DJ (1997) Extracorporeal support for intractable cardiorespiratory failure due to meningococcal disease. Lancet 349(9050):466-469. https://doi.org/10.1016/ s0140-6736(96)12106-1

10. Luyt D, Pridgeon J, Brown J, Peek G, Firmin R, Pandya H (2007) Extracorporeal life support for children with meningococcal septicaemia. Acta Paediatr 93(12):1608-1611. https://doi. org/10.1111/j.1651-2227.2004.tb00851.x

11. Weber TR, Kountzman B (1998) Extracorporeal membrane oxygenation for nonneonatal pulmonary and multiple-organ failure. J Pediatr Surg 33(11):1605-1609. https://doi.org/10.1016/S0022 -3468(98)90590-5

12. Maclaren G, Butt W, Best D, Donath S, Taylor A (2007) Extracorporeal membrane oxygenation for refractory septic shock in children: one institution's experience*. Pediatr Crit Care Med 8(5):447-451. https://doi.org/10.1097/01.pcc.0000282155.25974 $.8 \mathrm{f}$

13. Solé A, Jordan I, Bobillo S, Moreno J, Balaguer M, HernándezPlatero L, Segura S, Cambra FJ, Esteban E, Rodríguez-Fanjul J (2018) Venoarterial extracorporeal membrane oxygenation support for neonatal and pediatric refractory septic shock: more than 15 years of learning. Eur J Pediatr 177(8):1191-1200. https://doi. org/10.1007/s00431-018-3174-2

14. Maclaren G, Butt W, Best D, Donath S (2011) Central extracorporeal membrane oxygenation for refractory pediatric septic shock. Pediatr Crit Care Med 12(2):133-136. https://doi. org/10.1097/pcc.0b013e3181e2a4a1

15. Schlapbach LJ, Chiletti R, Straney L, Festa M, Alexander D, Butt W, Maclaren G (2019) Defining benefit threshold for extracorporeal membrane oxygenation in children with sepsisa binational multicenter cohort study. Crit Care. https://doi. org/10.1186/s13054-019-2685-1

16. Davis AL, Carcillo JA, Aneja RK, Deymann AJ, Lin JC, Nguyen TC, Okhuysen-Cawley RS, Relvas MS, Rozenfeld RA, Skippen PW, Stojadinovic BJ, Williams EA, Yeh TS, Balamuth F, Brierley J, De Caen AR, Cheifetz IM, Choong K, Conway E, Cornell T, Doctor A, Dugas M-A, Feldman JD, Fitzgerald JC, Flori HR, Fortenberry JD, Graciano AL, Greenwald BM, Hall MW, Han YY, Hernan LJ, Irazuzta JE, Iselin E, Van Der Jagt EW, Jeffries HE, Kache S, Katyal C, Kissoon N, Kon AA, Kutko MC, Maclaren G, Maul T, Mehta R, Odetola F, Parbuoni K, Paul R, Peters MJ, Ranjit S, Reuter-Rice KE, Schnitzler EJ, Scott HF, Torres A, Weingarten-Abrams J, Weiss SL, Zimmerman JJ, Zuckerberg AL (2017) American College of critical care medicine clinical practice parameters for hemodynamic support of pediatric and neonatal septic shock. Crit Care Med 45(6):10611093. https://doi.org/10.1097/ccm.0000000000002425
17. Lancaster TS, Eghtesady P (2018) State of the art in pediatric lung transplantation. Semin Thorac Cardiovasc Surg 30(2):166174. https://doi.org/10.1053/j.semtcvs.2018.04.007

18. Puri V, Epstein D, Raithel SC, Gandhi SK, Sweet SC, Faro A, Huddleston CB (2010) Extracorporeal membrane oxygenation in pediatric lung transplantation. J Thorac Cardiovasc Surg 140(2):427-432. https://doi.org/10.1016/j.jtcvs.2010.04.012

19. Kirshbom PM, Bridges ND, Myung RJ, Gaynor JW, Clark BJ, Spray TL (2002) Use of extracorporeal membrane oxygenation in pediatric thoracic organ transplantation. J Thorac Cardiovasc Surg 123(1):130-136. https://doi.org/10.1067/mtc.2002.118504

20. Toprak D, Midyat L, Freiberger D, Boyer D, Fynn-Thompson F, Visner G (2017) Outcomes of mechanical support in a pediatric lung transplant center. Pediatr Pulmonol 52(3):360-366. https:// doi.org/10.1002/ppul.23535

21. Olsen MC, Anderson MJ, Fehr JJ, Christensen JL, Shepard MP, Poe JB, Eghtesady P (2017) ECMO for pediatric lung transplantation. ASAIO J 63(6):e77-e80. https://doi.org/10.1097/ mat.0000000000000534

22. Hayes D, Galantowicz M, Yates AR, Preston TJ, Mansour HM, McConnell PI (2013) Venovenous ECMO as a bridge to lung transplant and a protective strategy for subsequent primary graft dysfunction. J Artif Org 16(3):382-385. https://doi.org/10.1007/ s10047-013-0699-z

23. Turner DA, Rehder KJ, Bonadonna D, Gray A, Lin S, Zaas D, Cheifetz IM (2014) Ambulatory ECMO as a bridge to lung transplant in a previously well pediatric patient with ARDS. Pediatrics 134(2):e583-e585

24. Hayes D, McConnell PI, Preston TJ, Yates AR, Kirkby S, Galantowicz M (2013) Active rehabilitation with venovenous extracorporeal membrane oxygenation as a bridge to lung transplantation in a pediatric patient. World J Pediatr 9(4):373-374. https://doi. org/10.1007/s12519-013-0437-x

25. Hayes D, Kukreja J, Tobias JD, Ballard HO, Hoopes CW (2012) Ambulatory venovenous extracorporeal respiratory support as a bridge for cystic fibrosis patients to emergent lung transplantation. J Cyst Fibros 11(1):40-45. https://doi.org/10.1016/j. jcf.2011.07.009

26. Church JT, Kim AC, Erickson KM, Rana A, Drongowski R, Hirschl RB, Bartlett RH, Mychaliska GB (2017) Pushing the boundaries of ECLS: outcomes in $<34$ week EGA neonates. J Pediatr Surg 52(11):1810-1815. https://doi.org/10.1016/j.jpeds urg.2017.03.054

27. Cilley RE, Zwischenberger JB, Andrews AF, Bowerman RA, Roloff DW, Bartlett RH (1986) Intracranial hemorrhage during extracorporeal membrane oxygenation in neonates. Pediatrics 78(4):699-704

28. Hirschl RB, Schumacher RE, Snedecor SN, Bui KC, Bartlett RH (1993) The efficacy of extracorporeal life support in premature and low birth weight newborns. J Pediatr Surg 28(10):13361340. https://doi.org/10.1016/s0022-3468(05)80324-0

29. Hardart GE, Hardart MKM, Arnold JH (2004) Intracranial hemorrhage in premature neonates treated with extracorporeal membrane oxygenation correlates with conceptional age. J Pediatr 145(2):184-189. https://doi.org/10.1016/j.jpeds.2004.04.012

30. Gadepalli SK, Hirschl RB (2015) Extracorporeal life support: updates and controversies. Semin Pediatr Surg 24(1):8-11. https ://doi.org/10.1053/j.sempedsurg.2014.11.002

31. Rozmiarek AJ, Qureshi FG, Cassidy L, Ford HR, Gaines BA, Rycus P, Hackam DJ (2004) How low can you go? Effectiveness and safety of extracorporeal membrane oxygenation in lowbirth-weight neonates. J Pediatr Surg 39(6):845-847. https://doi. org/10.1016/j.jpedsurg.2004.02.012

32. Cuevas Guamán M, Akinkuotu AC, Cruz SM, Griffiths PA, Welty SE, Lee TC, Olutoye OO (2018) Extracorporeal membrane oxygenation in premature infants with congenital diaphragmatic 
hernia. ASAIO J 64(5):e126-e129. https://doi.org/10.1097/ mat.0000000000000724

33. Radack DM, Baumgart S, Gross GW (1994) Subependymal (grade 1) intracranial hemorrhage in neonates on extracorporeal membrane oxygenation frequency and patterns of evolution. Clin Pediatr 33(10):583-587. https://doi.org/10.1177/0009922894 03301002

34. O'Connor TA, Haney BM, Grist GE, Egelhoff JC, Snyder CL, Ashcraft KW (1993) Decreased incidence of intracranial hemorrhage using cephalic jugular venous drainage during neonatal extracorporeal membrane oxygenation. J Pediatr Surg 28(10):1332-1335. https://doi.org/10.1016/S0022 -3468(05)80323-9

35. Jobe A (2016) Mechanisms of lung injury and bronchopulmonary dysplasia. Am J Perinatol 33(11):1076-1078. https://doi. org/10.1055/s-0036-1586107

36. Kneyber MCJ, Zhang H, Slutsky AS (2014) Ventilator-induced lung injury: similarity and differences between children and adults. Am J Respir Crit Care Med. https://doi.org/10.1164/ rccm.201401-0168cp

37. Lewis DA, Gauger P, Delosh TN, Dechert RE, Hirschl RB (1996) The effect of pre-ECLS ventilation time on survival and respiratory morbidity in the neonatal population. J Pediatr Surg 31(8):1110-1114. https://doi.org/10.1016/s0022-3468(96)90098 $-6$

38. Zabrocki LA, Brogan TV, Statler KD, Poss WB, Rollins MD, Bratton SL (2011) Extracorporeal membrane oxygenation for pediatric respiratory failure: survival and predictors of mortality. Crit Care Med 39(2):364-370. https://doi.org/10.1097/ ccm.0b013e3181fb7b35

39. Domico MB, Ridout DA, Bronicki R, Anas NG, Cleary JP, Cappon J, Goldman AP, Brown KL (2012) The impact of mechanical ventilation time before initiation of extracorporeal life support on survival in pediatric respiratory failure. Pediatr Crit Care Med 13(1):16-21. https://doi.org/10.1097/pcc.0b013e3182192c66

40. Barbaro RP, Paden ML, Guner YS, Raman L, Ryerson LM, Alexander P, Nasr VG, Bembea MM, Rycus PT, Thiagarajan RR (2017) Pediatric extracorporeal life support organization registry International Report 2016. ASAIO J 63(4):456-463. https://doi. org/10.1097/mat.0000000000000603

41. Huang SC, Wu ET, Wang CC, Chen YS, Chang CI, Chiu IS, Ko WJ, Wang SS (2012) Eleven years of experience with extracorporeal cardiopulmonary resuscitation for paediatric patients with in-hospital cardiac arrest. Resuscitation 83(6):710-714. https:// doi.org/10.1016/j.resuscitation.2012.01.031

42. Prodhan P, Fiser RT, Dyamenahalli U, Gossett J, Imamura M, Jaquiss RDB, Bhutta AT (2009) Outcomes after extracorporeal cardiopulmonary resuscitation (ECPR) following refractory pediatric cardiac arrest in the intensive care unit. Resuscitation 80(10):1124-1129. https://doi.org/10.1016/j.resuscitat ion.2009.07.004

43. Westin B, Nyberg R (1958) Enhorning G (1958) A technique for perfusion of the previable human fetus. Acta Paediatr 47(4):339-349

44. Partridge EA, Davey MG, Hornick MA, McGovern PE, Mejaddam AY, Vrecenak JD, Mesas-Burgos C, Olive A, Caskey RC, Weiland TR, Han J, Schupper AJ, Connelly JT, Dysart KC, Rychik J, Hedrick HL, Peranteau WH, Flake AW (2017) An extra-uterine system to physiologically support the extreme premature lamb. Nat Commun 8:15112. https://doi.org/10.1038/ ncomms 15112

45. Usuda H, Watanabe S, Miura Y, Saito M, Musk GC, Rittenschober-Bohm J, Ikeda H, Sato S, Hanita T, Matsuda T, Jobe AH, Newnham JP, Stock SJ, Kemp MW (2017) Successful maintenance of key physiological parameters in preterm lambs treated with ex vivo uterine environment therapy for a period of
1 week. Am J Obstet Gynecol 217(4):457.e451-457.e413. https ://doi.org/10.1016/j.ajog.2017.05.046

46. Church JT, Coughlin MA, Perkins EM, Hoffman HR, Barks JD, Rabah R, Bentley JK, Hershenson MB, Bartlett RH, Mychaliska GB (2018) The artificial placenta: Continued lung development during extracorporeal support in a preterm lamb model. J Pediatr Surg. https://doi.org/10.1016/j.jpedsurg.2018.06.001

47. Church JT, Perkins EM, Coughlin MA, McLeod JS, Boss K, Bentley JK, Hershenson MB, Rabah R, Bartlett RH, Mychaliska GB (2018) Perfluorocarbons prevent lung injury and promote development during artificial placenta support in extremely premature lambs. Neonatology 113(4):313-321. https://doi.org/10.1159/000486387

48. Church JT, Werner NL, Coughlin MA, Menzel-Smith J, Najjar M, Carr BD, Parmar H, Neil J, Alexopoulos D, Perez-Torres C, Ge X, Beeman SC, Garbow JR, Mychaliska GB (2018) Effects of an artificial placenta on brain development and injury in premature lambs. J Pediatr Surg 53(6):1234-1239. https://doi. org/10.1016/j.jpedsurg.2018.02.091

49. McGovern PE, Hornick MA, Mejaddam AY, Lawrence K, Schupper AJ, Rossidis AC, Baumgarten H, Vossough A, Didier RA, Kim A, Partridge EA, Hwang G, Young K, Peranteau WH, Davey MG, Flake AW (2020) Neurologic outcomes of the premature lamb in an extrauterine environment for neonatal development. J Pediatr Surg. https://doi.org/10.1016/j.jpeds urg.2019.12.026

50. McLeod JS, Church JT, Coughlin MA, Carr B, Poling C, Sarosi E, Perkins EM, Quinones MC, Hala P, Rabah R, Freiheit E, Rojas-Pena A, Bartlett RH, Mychaliska GB (2019) Splenic development and injury in premature lambs supported by the artificial placenta. J Pediatr Surg 54(6):1147-1152. https://doi. org/10.1016/j.jpedsurg.2019.02.041

51. McLeod JS, Church JT, Yerramilli P, Coughlin MA, Perkins EM, Rabah R, Bartlett RH, Rojas-Pena A, Greenson JK, Perrone EE, Mychaliska GB (2018) Gastrointestinal mucosal development and injury in premature lambs supported by the artificial placenta. J Pediatr Surg 53(6):1240-1245. https://doi. org/10.1016/j.jpedsurg.2018.02.092

52. Baumgarten HD, Wright CM, Rossidis AC, Lawrence KM, Kim AG, Mejaddam AY, McGovern PE, Orr MN, Coons BE, Butt Z, Li H, Hwang G, Radu A, Brown LJ, Rubenstein RC, Peranteau WH, Davey M, Heuckeroth RO, Flake AW (2020) The EXTra-uterine Environment for Neonatal Development supports normal intestinal maturation and development. Cell Mol Gastroenterol Hepatol. https://doi.org/10.1016/j.jcmgh .2020.05.006

53. Usuda H, Watanabe S, Saito M, Sato S, Musk GC, Fee ME, Carter S, Kumagai Y, Takahashi T, Kawamura MS, Hanita T, Kure S, Yaegashi N, Newnham JP, Kemp MW (2019) Successful use of an artificial placenta to support extremely preterm ovine fetuses at the border of viability. Am J Obstet Gynecol 221(1):69. e61-69.e17. https://doi.org/10.1016/j.ajog.2019.03.001

54. Hornick MA, Mejaddam AY, McGovern PE, Hwang G, Han J, Peranteau WH, Partridge EA, Davey MG, Flake AW (2019) Technical feasibility of umbilical cannulation in midgestation lambs supported by the EXTra-uterine Environment for Neonatal Development (EXTEND). Artif Org 43(12):1154-1161. https:// doi.org/10.1111/aor.13524

55. Dong E, Du H, Gardner L (2020) An interactive web-based dashboard to track COVID-19 in real time. Lancet Infect Dis 20(5):533-534. https://doi.org/10.1016/s1473-3099(20)30120-1

56. Guan W-J, Ni Z-Y, Hu Y, Liang W-H, Ou C-Q, He J-X, Liu L, Shan H, Lei C-L, Hui DSC, Du B, Li L-J, Zeng G, Yuen K-Y, Chen R-C, Tang C-L, Wang T, Chen P-Y, Xiang J, Li S-Y, Wang J-L, Liang Z-J, Peng Y-X, Wei L, Liu Y, Hu Y-H, Peng P, Wang J-M, Liu J-Y, Chen Z, Li G, Zheng Z-J, Qiu S-Q, Luo J, Ye C-J, 
Zhu S-Y, Zhong N-S (2020) Clinical characteristics of coronavirus disease 2019 in China. N Engl J Med 382(18):1708-1720. https://doi.org/10.1056/nejmoa2002032

57. Ludvigsson JF (2020) Systematic review of COVID-19 in children shows milder cases and a better prognosis than adults. Acta Paediatr 109(6):1088-1095. https://doi.org/10.1111/apa.15270

58. Lee P-I, Hu Y-L, Chen P-Y, Huang Y-C, Hsueh P-R (2020) Are children less susceptible to COVID-19? J Microbiol Immunol Infect 53(3):371-372. https://doi.org/10.1016/j.jmii.2020.02.011

59. Dong Y, Mo X, Hu Y, Qi X, Jiang F, Jiang Z, Tong S (2020) Epidemiology of COVID-19 Among children in China. Pediatrics 145(6):e20200702. https://doi.org/10.1542/ peds.2020-0702

60. Parri N, Lenge M, Buonsenso D (2020) Children with Covid-19 in Pediatric Emergency Departments in Italy. N Engl J Med. https ://doi.org/10.1056/nejmc2007617

61. Castagnoli R, Votto M, Licari A, Brambilla I, Bruno R, Perlini S, Rovida F, Baldanti F, Marseglia GL (2020) Severe acute respiratory syndrome coronavirus 2 (SARS-CoV-2) infection in children and adolescents. JAMA Pediatr. https://doi.org/10.1001/jamap ediatrics.2020.1467

62. Shekerdemian LS, Mahmood NR, Wolfe KK, Riggs BJ, Ross CE, McKiernan CA, Heidemann SM, Kleinman LC, Sen AI, Hall MW, Priestley MA, McGuire JK, Boukas K, Sharron MP, Burns JP (2020) Characteristics and outcomes of children with coronavirus disease 2019 (COVID-19) infection admitted to US and Canadian Pediatric Intensive Care Units. JAMA Pediatr. https:// doi.org/10.1001/jamapediatrics.2020.1948

63. Henry BM, Lippi G (2020) Poor survival with extracorporeal membrane oxygenation in acute respiratory distress syndrome (ARDS) due to coronavirus disease 2019 (COVID-19): Pooled analysis of early reports. J Crit Care 58:27-28. https://doi. org/10.1016/j.jcrc.2020.03.011

64. Barbaro RP, Maclaren G, Boonstra PS, Iwashyna TJ, Slutsky AS, Fan E, Bartlett RH, Tonna JE, Hyslop R, Fanning JJ, Rycus PT, Hyer SJ, Anders MM, Agerstrand CL, Hryniewicz K, Diaz R, Lorusso R, Combes A, Brodie D, Alexander P, Barrett N, Bělohlávek J, Fisher D, Fraser J, Hssain AA, Jung JS, McMullan M, Mehta Y, Ogino MT, Paden ML, Shekar K, Stead C, AbuOmar Y, Agnoletti V, Akbar A, Alfoudri H, Alviar C, Aronsky V, August E, Auzinger G, Aveja H, Bakken R, Balcells J, Bangalore S, Barnes BW, Bautista A, Bellows LL, Beltran F, Benharash P, Benni M, Berg J, Bertini P, Blanco-Schweizer P, Brunsvold M, Budd J, Camp D, Caridi-Scheible M, Carton E, Casanova-Ghosh E, Castleberry A, Chipongian CT, Choi CW, Circelli A, Cohen E, Collins M, Copus S, Coy J, Crist B, Cruz L, Czuczwar M, Daneshmand M, Davis Ii D, De La Cruz K, Devers C, Duculan T, Durham L, Elapavaluru S, Elzo Kraemer CV, Filho EC, Fitzgerald J, Foti G, Fox M, Fritschen D, Fullerton D, Gelandt E, Gerle S, Giani M, Goh SG, Govener S, Grone J, Guber M, Gudzenko V, Gutteridge D, Guy J, Haft J, Hall C, Hassan IF, Herrán R, Hirose $\mathrm{H}$, Ibrahim AS, Igielski D, Ivascu FA, Izquierdo Blasco J, Jackson J, Jain H, Jaiswal B, Johnson AC, Jurynec JA, Kellter NM, Kohl A, Kon Z, Kredel M, Kriska K, Kunavarapu C, LansinkHartgring O, Larocque J, Larson SB, Layne T, Ledot S, Lena N, Lillie J, Lotz G, Lucas M, Ludwigson L, Maas JJ, Maertens J, Mast D, McCardle S, McDonald B, McLarty A, McMahon C, Meybohm P, Meyns B, Miller C, Moraes Neto F, Morris K, Muellenbach R, Nicholson M, O'Brien S, O'Keefe K, Ogston T, Oldenburg G, Oliveira FM, Oppel E, Pardo D, Pardo D, Parker SJ, Pedersen FM, Pellecchia C, Pelligrini JAS, Pham TTN, Phillips AR, Pirani T, Piwowarczyk P, Plambeck R, Pruett W, Quandt B, Ramanathan K, Rey A, Reyher C, Riera Del Brio J, Roberts R, Roe D, Roeleveld PP, Rudy J, Rueda LF, Russo E, Sánchez Ballesteros J, Satou N, Saueressig MG, Saunders PC, Schlotterbeck M, Schwarz P, Scriven N, Serra A, Shamsah M, Sim L,
Smart A, Smith A, Smith D, Smith M, Sodha N, Sonntagbauer M, Sorenson M, Stallkamp EB, Stewart A, Swartz K, Takeda K, Thompson S, Toy B, Tuazon D, Uchiyama M, Udeozo OI, Van Poppel S, Ventetuolo C, Vercaemst L, Vinh Chau NV, Wang IW, Williamson C, Wilson B, Winkels H (2020) Extracorporeal membrane oxygenation support in COVID-19: an international cohort study of the Extracorporeal Life Support Organization registry. Lancet 396(10257):1071-1078. https://doi.org/10.1016/ s0140-6736(20)32008-0

65. Di Nardo M, Hoskote A, Thiruchelvam T, Lillie J, Horan M, Belda Hofheinz S, Dupic L, Gimeno R, De Piero ME, Lo Coco V, Roeleveld P, Davidson M, Jones T, Broman LM, Lorusso R, Belohvalek J (2020) Extracorporeal membrane oxygenation in children with COVID-19. ASAIO J Publish Ahead of. https://doi. org/10.1097/mat.0000000000001309

66. Oualha M, Bendavid M, Berteloot L, Corsia A, Lesage F, Vedrenne M, Salvador E, Grimaud M, Chareyre J, De Marcellus C, Dupic L, Heilbronner C, Drummond D, Castelle M, Berthaud R, Angoulvant F, Toubiana J, Pinhas Y, Frange P, Chéron G, Fourgeaud J, Moulin F, Renolleau S (2020) Severe and fatal forms of COVID-19 in children. Arch Pédiatr 27(5):235-238. https://doi.org/10.1016/j.arcped.2020.05.010

67. Belhadjer Z, Méot M, Bajolle F, Khraiche D, Legendre A, Abakka S, Auriau J, Grimaud M, Oualha M, Beghetti M, Wacker J, Ovaert C, Hascoet S, Selegny M, Malekzadeh-Milani S, Maltret A, Bosser G, Giroux N, Bonnemains L, Bordet J, Di Filippo S, Mauran P, Falcon-Eicher S, Thambo J-B, Lefort B, Moceri P, Houyel L, Renolleau S, Bonnet D (2020) Acute heart failure in multisystem inflammatory syndrome in children (MIS-C) in the context of global SARS-CoV-2 pandemic. Circulation. https:// doi.org/10.1161/circulationaha.120.048360

68. Whittaker E, Bamford A, Kenny J, Kaforou M, Jones CE, Shah P, Ramnarayan P, Fraisse A, Miller O, Davies P, Kucera F, Brierley J, McDougall M, Carter M, Tremoulet A, Shimizu C, Herberg J, Burns JC, Lyall H, Levin M (2020) Clinical characteristics of 58 children with a pediatric inflammatory multisystem syndrome temporally associated with SARS-CoV-2. JAMA. https:// doi.org/10.1001/jama.2020.10369

69. Kaushik S, Aydin SI, Derespina KR, Bansal PB, Kowalsky S, Trachtman R, Gillen JK, Perez MM, Soshnick SH, Conway EE, Bercow A, Seiden HS, Pass RH, Ushay HM, Ofori-Amanfo G, Medar SS (2020) Multisystem Inflammatory syndrome in children (MIS-C) associated with SARS-CoV-2 infection: a multiinstitutional study from New York City. J Pediatr. https://doi. org/10.1016/j.jpeds.2020.06.045

70. Broman LM, Taccone FS, Lorusso R, Malfertheiner MV, Pappalardo F, Di Nardo M, Belliato M, Bembea MM, Barbaro RP, Diaz R, Grazioli L, Pellegrino V, Mendonca MH, Brodie D, Fan E, Bartlett RH, McMullan MM, Conrad SA (2019) The ELSO Maastricht Treaty for ECLS Nomenclature: abbreviations for cannulation configuration in extracorporeal life support-a position paper of the Extracorporeal Life Support Organization. Crit Care. https://doi.org/10.1186/s13054-019-2334-8

71. Bartlett RH (2017) Esperanza. ASAIO J 63(6):832-843. https:// doi.org/10.1097/mat.0000000000000697

72. Bartlett RH, Andrews AF, Toomasian JM, Haiduc NJ, Gazzaniga AB (1982) Extracorporeal membrane oxygenation for newborn respiratory failure: forty-five cases. Surgery 92(2):425-433

73. Garcia AV, Jeyaraju M, Ladd MR, Jelin EB, Bembea MM, Alaish S, Rhee D (2018) Survey of the American Pediatric Surgical Association on cannulation practices in pediatric ECMO. J Pediatr Surg 53(9):1843-1848. https://doi.org/10.1016/j.jpeds urg.2017.11.046

74. Johnson K, Jarboe MD, Mychaliska GB, Barbaro RP, Rycus P, Hirschl RB, Gadepalli SK (2018) Is there a best approach for extracorporeal life support cannulation: a review of the 
extracorporeal life support organization. J Pediatr Surg 53(7):1301-1304. https://doi.org/10.1016/j.jpedsurg.2018.01.015

75. Barrett CS, Bratton SL, Salvin JW, Laussen PC, Rycus PT, Thiagarajan RR (2009) Neurological injury after extracorporeal membrane oxygenation use to aid pediatric cardiopulmonary resuscitation. Pediatr Crit Care Med 10(4):445-451. https://doi. org/10.1097/pcc.0b013e318198bd85

76. Kato J, Seo T, Ando H, Takagi H, Ito T (1996) Coronary arterial perfusion during venoarterial extracorporeal membrane oxygenation. J Thorac Cardiovasc Surg 111(3):630-636. https ://doi.org/10.1016/s0022-5223(96)70315-X

77. Seo T, Ito T, Iio K, Kato J, Takagi H (1991) Experimental study on the hemodynamic effects of veno-arterial extracorporeal membrane oxygenation with an automatically driven blood pump on puppies. Artif Org 15(5):402-407

78. Roeleveld PP, Mendonca M (2019) Neonatal cardiac ECMO in 2019 and beyond. Front Pediatr. https://doi.org/10.3389/ fped.2019.00327

79. Ostadal P, Mlcek M, Kruger A, Hala P, Lacko S, Mates M, Vondrakova D, Svoboda T, Hrachovina M, Janotka M, Psotova H, Strunina S, Kittnar O, Neuzil P (2015) Increasing venoarterial extracorporeal membrane oxygenation flow negatively affects left ventricular performance in a porcine model of cardiogenic shock. J Transl Med. https://doi.org/10.1186/s12967-015-0634-6

80. Drucker NA, Wang SK, Markel TA, Landman MP, Gray BW (2019) Practice patterns in imaging guidance for ECMO cannulation: a survey of the American Pediatric Surgical Association. J Pediatr Surg. https://doi.org/10.1016/j.jpedsurg.2019.11.010

81. Grant C Jr, Richards JB, Frakes M, Cohen J, Wilcox SR (2020) ECMO and right ventricular failure: review of the literature. J Intens Care Med. https://doi.org/10.1177/0885066619900503

82. Speggiorin S, Robinson S, Harvey C, Westrope C, Faulkner G, Kirkland P, Peek G (2015) Experience with the Avalon ${ }^{\circledR}$ bicaval double-lumen veno-venous cannula for neonatal respiratory ECMO. Perfusion 30(3):250-254. https://doi.org/10.1177/02676 59114540020

83. Klein MD, Andrews AF, Wesley JR, Toomasian J, Nixon C, Roloff D, Bartlett RH (1985) Venovenous perfusion in ECMO for newborn respiratory insufficiency. Ann Surg 201(4):520-526. https://doi.org/10.1097/00000658-198504000-00019

84. Bunge JJH, Caliskan K, Gommers D, Miranda DR (2018) Right ventricular dysfunction during acute respiratory distress syndrome and veno-venous extracorporeal membrane oxygenation. J Thorac Dis 10(S5):S674-S682. https://doi.org/10.21037/ jtd.2017.10.75

85. Biscotti M, Lee A, Basner RC, Agerstrand C, Abrams D, Brodie D, Bacchetta M (2014) Hybrid configurations via percutaneous access for extracorporeal membrane oxygenation. ASAIO J 60(6):635-642. https://doi.org/10.1097/mat.0000000000000139

86. Kinsella JP, Gerstmann DR, Rosenberg AA (1992) The effect of extracorporeal membrane oxygenation on coronary perfusion and regional blood flow distribution. Pediatr Res 31(1):80-84. https ://doi.org/10.1203/00006450-199201000-00015

87. Gander JW, Fisher JC, Reichstein AR, Gross ER, Aspelund G, Middlesworth W, Stolar CJ (2010) Limb ischemia after common femoral artery cannulation for venoarterial extracorporeal membrane oxygenation: an unresolved problem. J Pediatr Surg 45(11):2136-2140. https://doi.org/10.1016/j.jpeds urg.2010.07.005

88. Kasirajan V, Simmons I, King J, Shumaker M, DeAnda A, Higgins R (2002) Technique to prevent limb ischemia during peripheral cannulation for extracorporeal membrane oxygenation. Perfusion 17(6):427-428

89. Greason KL, Hemp JR, Maxwell JM, Fetter JE, MorenoCabral RJ (1995) Prevention of distal limb ischemia during cardiopulmonary support via femoral cannulation. Ann Thorac Surg 60(1):209-210. https://doi.org/10.1016/s0003 $-4975(95) 00380-0$

90. Haley MJ, Fisher JC, Ruiz-Elizalde AR, Stolar CJH, Morrissey NJ, Middlesworth W (2009) Percutaneous distal perfusion of the lower extremity after femoral cannulation for venoarterial extracorporeal membrane oxygenation in a small child. J Pediatr Surg 44(2):437-440. https://doi.org/10.1016/j.jpedsurg.2008.09.010

91. Spurlock D, Toomasian J, Romano M, Cooley E, Bartlett R, Haft J (2012) A simple technique to prevent limb ischemia during veno-arterial ECMO using the femoral artery: the posterior tibial approach. Perfusion 27(2):141-145. https://doi. org/10.1177/0267659111430760

92. Schad CA, Fallon BP, Monteagudo J, Okochi S, Cheung EW, Morrissey NJ, Kadenhe-Chiweshe AV, Aspelund G, Stylianos S, Middlesworth W (2017) Routine use of distal arterial perfusion in pediatric femoral venoarterial extracorporeal membrane oxygenation. Artif Org 41(1):11-16. https://doi.org/10.1111/ aor. 12861

93. Fraser CD, Kovler ML, Guzman W, Rhee DS, Lum YW, Alaish SM, Garcia AV (2019) Pediatric femoral arterial cannulations in extracorporeal membrane oxygenation. ASAIO J 65(7):636-641. https://doi.org/10.1097/mat.0000000000000884

94. Jackson KW, Timpa J, McIlwain RB, O'Meara C, Kirklin JK, Borasino S, Alten JA (2012) Side-arm grafts for femoral extracorporeal membrane oxygenation cannulation. Ann Thorac Surg 94(5):e111-e112. https://doi.org/10.1016/j.athoracsur .2012.05.064

95. Doll N, Kiaii B, Borger M, Bucerius J, Krämer K, Schmitt DV, Walther T, Mohr FW (2004) Five-year results of 219 consecutive patients treated with extracorporeal membrane oxygenation for refractory postoperative cardiogenic shock. Ann Thorac Surg 77(1):151-157. https://doi.org/10.1016/S0003-4975(03)01329-8

96. Quarti A, Iezzi F, Santoro G, Pozzi M (2014) Femoral artery cannulation through a side graft in extracorporeal membrane oxygenation. Heart Lung Vessel 6(2):125-127

97. Kyo M, Ohshimo S, Kida Y, Shimatani T, Torikoshi Y, Suzuki K, Yamaga S, Hirohashi N, Shime N (2016) Pediatric cardiorespiratory failure successfully managed with venoarterial-venous extracorporeal membrane oxygenation: a case report. BMC Pulm Med. https://doi.org/10.1186/s12890-016-0280-7

98. Werner NL, Coughlin M, Cooley E, Haft JW, Hirschl RB, Bartlett RH, Mychaliska GB (2016) The University of Michigan experience with veno-venoarterial hybrid mode of extracorporeal membrane oxygenation. ASAIO J 62(5):578-583. https://doi. org/10.1097/mat.0000000000000405

99. Iyengar A, Zhu A, Samson J, Reemtsen B, Biniwale R (2016) Childhood obesity and extracorporeal membrane oxygenation: special considerations for successful outcomes. J Pediatr Intens Care 06(02):109-116. https://doi.org/10.1055/s-0036-1584681

100. Bernard P, Skinner S, Bhandary P, Ruzic A, Bacon M, Ballard H, Daniel J (2018) Hollow fiber oxygenator composition has a significant impact on failure rates in neonates on extracorporeal membrane oxygenation: a retrospective analysis. J Pediatr Intens Care 07(01):007-013. https://doi.org/10.1055/s-0037-1599150

101. Khoshbin E, Roberts N, Harvey C, Machin D, Killer H, Peek GJ, Sosnowski AW, Firmin RK (2005) Poly-methyl pentene oxygenators have improved gas exchange capability and reduced transfusion requirements in adult extracorporeal membrane oxygenation. Cardiovasc Thorac Surg 51(3):281-287. https://doi. org/10.1097/01.mat.0000159741.33681.f1

102. Corno AF, Faulkner GM, Harvey C (2020) Mobile extracorporeal membrane oxygenation. ASAIO J Online First. https://doi. org/10.1097/mat.0000000000001286

103. Gorbet MB, Sefton MV (2004) Biomaterial-associated thrombosis: roles of coagulation factors, complement, platelets 
and leukocytes. Biomaterials 25(26):5681-5703. https://doi. org/10.1016/j.biomaterials.2004.01.023

104. Fosse E, Moen O, Johnson E, Semb G, Brockmeier V, Mollnes TE, Fagerhol MK, Venge P (1994) Reduced complement and granulocyte activation with heparin-coated cardiopulmonary bypass. Ann Thorac Surg 58(2):472-477. https://doi. org/10.1016/0003-4975(94)92231-4

105. Weerwind PW, Maessen JG, Van Tits LJH, Stad RK, Fransen EJ, De Jong DS, Penn OCKM (1995) Influence of Duraflo II heparin-treated extracorporeal circuits on the systemic inflammatory response in patients having coronary bypass. J Thorac Cardiovasc Surg 110(6):1633-1641. https://doi.org/10.1016/ s0022-5223(95)70024-2

106. Sohn N, Marcoux J, Mycyk T, Krahn J, Meng Q (2009) The impact of different biocompatible coated cardiopulmonary bypass circuits on inflammatory response and oxidative stress. Perfusion 24(4):231-237. https://doi.org/10.1177/0267659109 351218

107. Ontaneda A, Annich GM (2018) Novel surfaces in extracorporeal membrane oxygenation circuits. Front Med. https://doi. org/10.3389/fmed.2018.00321

108. Koster A, Sänger S, Hansen R, Sodian R, Mertzlufft F, Harke C, Kuppe H, Hetzer R, Loebe M (2000) Prevalence and persistence of heparin/platelet factor 4 antibodies in patients with heparin coated and noncoated ventricular assist devices. ASAIO J 46(3):319-322

109. Silvetti S, Koster A, Pappalardo F (2015) Do we need heparin coating for extracorporeal membrane oxygenation? New concepts and controversial positions about coating surfaces of extracorporeal circuits. Artif Org 39(2):176-179. https://doi. org/10.1111/aor.12335

110. Thiara A, Andersen V, Videm V, Mollnes T, Svennevig K, Hoel T, Fiane A (2010) Comparable biocompatibility of phisio- and bioline-coated cardiopulmonary bypass circuits indicated by the inflammatory response. Perfusion 25(1):9-16. https://doi. org/10.1177/0267659110362822

111. Wang Y-B, Shi K-H, Jiang H-L, Gong Y-K (2016) Significantly reduced adsorption and activation of blood components in a membrane oxygenator system coated with crosslinkable zwitterionic copolymer. Acta Biomater 40:153-161. https://doi. org/10.1016/j.actbio.2016.02.036

112. Ranucci M, Isgrò G, Soro G, Canziani A, Menicanti L, Frigiola A (2004) Reduced systemic heparin dose with phosphorylcholine coated closed circuit in coronary operations. Int J Artif Org 27(4):311-319. https://doi.org/10.1177/039139880402700407

113. Major TC, Brant DO, Reynolds MM, Bartlett RH, Meyerhoff ME, Handa H, Annich GM (2010) The attenuation of platelet and monocyte activation in a rabbit model of extracorporeal circulation by a nitric oxide releasing polymer. Biomaterials 31(10):2736-2745. https://doi.org/10.1016/j.biomateria 1s. 2009.12 .028

114. Brisbois EJ, Major TC, Goudie MJ, Bartlett RH, Meyerhoff ME, Handa H (2016) Improved hemocompatibility of silicone rubber extracorporeal tubing via solvent swelling-impregnation of $S$-nitroso- $N$-acetylpenicillamine (SNAP) and evaluation in rabbit thrombogenicity model. Acta Biomater 37:111-119. https://doi. org/10.1016/j.actbio.2016.04.025

115. Major TC, Brisbois EJ, Jones AM, Zanetti ME, Annich GM, Bartlett RH, Handa H (2014) The effect of a polyurethane coating incorporating both a thrombin inhibitor and nitric oxide on hemocompatibility in extracorporeal circulation. Biomaterials 35(26):7271-7285. https://doi.org/10.1016/j.biomateria 1s.2014.05.036

116. Brisbois EJ, Davis RP, Jones AM, Major TC, Bartlett RH, Meyerhoff ME, Handa H (2015) Reduction in thrombosis and bacterial adhesion with 7 day implantation of
$S$-nitroso- $N$-acetylpenicillamine (SNAP)-doped Elast-eon E2As catheters in sheep. J Mater Chem B 3(8):1639-1645. https://doi. org/10.1039/c4tb02036g

117. Hopkins SP, Pant J, Goudie MJ, Schmiedt C, Handa H (2018) Achieving long-term biocompatible silicone via covalently immobilized $S$-nitroso- $N$-acetylpenicillamine (SNAP) that exhibits 4 months of sustained nitric oxide release. ACS Appl Mater Interfaces 10(32):27316-27325. https://doi.org/10.1021/acsam i. $8 \mathrm{~b} 08647$

118. Rossidis AC, Lawrence KM, Mejaddam AY, Kim AG, Baumgarten HD, Coons BE, Young K, Monos S, Hwang G, Flake AW, Davey MG (2020) The effects of nitric oxide in oxygenator sweep gas during extracorporeal circulation in a neonatal ovine model. ASAIO J 66(6):671-676. https://doi.org/10.1097/ mat.0000000000001047

119. Toomasian JM, Jeakle MMP, Langley MW, Poling CJ, Lautner G, Lautner-Csorba O, Meyerhoff MM, Carr BJD, Rojas-Pena A, Haft JW, Bartlett RH (2020) Nitric oxide attenuates the inflammatory effects of air during extracorporeal circulation. ASAIO J 66(7):818-824. https://doi.org/10.1097/mat.00000 00000001057

120. James C, Millar J, Horton S, Brizard C, Molesworth C, Butt W (2016) Nitric oxide administration during paediatric cardiopulmonary bypass: a randomised controlled trial. Intensive Care Med 42(11):1744-1752. https://doi.org/10.1007/s0013 4-016-4420-6

121. Lequier L, Horton SB, McMullan DM, Bartlett RH (2013) Extracorporeal membrane oxygenation circuitry. Pediatr Crit Care Med 14:S7-S12. https://doi.org/10.1097/pcc.0b013e318292dd10

122. Extracorporeal Life Support Organization (2013) ELSO guidelines for cardiopulmonary extracorporeal life support. ELSO, Ann Arbor

123. Bartlett RH (2016) ECMO: the next ten years. Egypt J Crit Care Med 4(1):7-10. https://doi.org/10.1016/j.ejccm.2016.01.003

124. Biscotti M, Gannon WD, Agerstrand C, Abrams D, Sonett J, Brodie D, Bacchetta M (2017) Awake extracorporeal membrane oxygenation as bridge to lung transplantation: a 9-year experience. Ann Thorac Surg 104(2):412-419. https://doi.org/10.1016/j.athor acsur.2016.11.056

125. Abrams D, Javidfar J, Farrand E, Mongero LB, Agerstrand CL, Ryan P, Zemmel D, Galuskin K, Morrone TM, Boerem P, Bacchetta M, Brodie D (2014) Early mobilization of patients receiving extracorporeal membrane oxygenation: a retrospective cohort study. Crit Care 18(1):R38. https://doi.org/10.1186/cc13746

126. Madhani SP, Frankowski BJ, Ye S-H, Burgreen GW, Wagner WR, Kormos R, D’Cunha J, Federspiel WJ (2019) In vivo 5 day animal studies of a compact, wearable pumping artificial lung. ASAIO J 65(1):94-100. https://doi.org/10.1097/mat.0000000000 000740

127. Liu Y, Sanchez PG, Wei X, Watkins AC, Niu S, Wu ZJ, Griffith BP (2015) Effects of cardiopulmonary support with a novel pediatric pump-lung in a 30-day ovine animal model. Artif Org 39(12):989-997. https://doi.org/10.1111/aor.12487

128. Wei X, Sanchez PG, Liu Y, Claire Watkins A, Li T, Griffith BP, Wu ZJ (2016) Extracorporeal respiratory support with a miniature integrated pediatric pump-lung device in an acute ovine respiratory failure model. Artif Org 40(11):1046-1053. https:// doi.org/10.1111/aor.12705

129. Lancaster TS, Miller JR, Epstein DJ, DuPont NC, Sweet SC, Eghtesady P (2017) Improved waitlist and transplant outcomes for pediatric lung transplantation after implementation of the lung allocation score. J Heart Lung Transplant 36(5):520-528

130. Hoganson DM, Gazit AZ, Boston US, Sweet SC, Grady RM, Huddleston CB, Eghtesady P (2014) Paracorporeal lung assist devices as a bridge to recovery or lung transplantation in neonates 
and young children. J Thorac Cardiovasc Surg 147(1):420-427. https://doi.org/10.1016/j.jtcvs.2013.08.078

131. Strueber M, Hoeper MM, Fischer S, Cypel M, Warnecke G, Gottlieb J, Pierre A, Welte T, Haverich A, Simon AR, Keshavjee S (2009) Bridge to thoracic organ transplantation in patients with pulmonary arterial hypertension using a pumpless lung assist device. Am J Transplant 9(4):853-857. https://doi.org/10.111 1/j.1600-6143.2009.02549.x

132. Thompson AJ, Buchan S, Carr B, Poling C, Hayes M, Fernando UP, Kaesler A, Schlanstein P, Hesselmann F, Arens J, Potkay JA, Rojas-Peña A, Bartlett RH, Hirschl RB (2020) Low-resistance, concentric-gated pediatric artificial lung for end-stage lung failure. ASAIO J 66(4):423-432. https://doi.org/10.1097/mat.00000 00000001018

133. May AG, Orizondo RA, Frankowski BJ, Wearden PD, Federspiel WJ (2019) Acute in vivo evaluation of the Pittsburgh pediatric ambulatory lung. ASAIO J 65(4):395-400. https://doi. org/10.1097/mat.0000000000000918

134. Barton R, Ignjatovic V, Monagle P (2019) Anticoagulation during ECMO in neonatal and paediatric patients. Thromb Res 173:172-177. https://doi.org/10.1016/j.thromres.2018.05.009

135. Niebler RA, Christensen M, Berens R, Wellner H, Mikhailov T, Tweddell JS (2011) Antithrombin replacement during extracorporeal membrane oxygenation. Artif Org 35(11):1024-1028. https://doi.org/10.1111/j.1525-1594.2011.01384.x

136. Byrnes JW, Swearingen CJ, Prodhan P, Fiser R, Dyamenahalli U (2014) Antithrombin III supplementation on extracorporeal membrane oxygenation: impact on heparin dose and circuit life. ASAIO J 60(1):57-62. https://doi.org/10.1097/mat.0000000000 000010

137. Todd Tzanetos DR, Myers J, Wells T, Stewart D, Fanning JJ, Sullivan JE (2017) The use of recombinant antithrombin III in pediatric and neonatal ECMO patients. ASAIO J 63(1):93-98. https://doi.org/10.1097/mat.0000000000000476

138. Wong TE, Nguyen T, Shah SS, Brogan TV, Witmer CM (2016) Antithrombin concentrate use in pediatric extracorporeal membrane oxygenation. Pediatr Crit Care Med 17(12):1170-1178. https://doi.org/10.1097/pcc.0000000000000955

139. Ranucci M (2012) Bivalirudin and post-cardiotomy ECMO: a word of caution. Crit Care. https://doi.org/10.1186/cc11314

140. Sanfilippo F, Asmussen S, Maybauer DM, Santonocito C, Fraser JF, Erdoes G, Maybauer MO (2017) Bivalirudin for alternative anticoagulation in extracorporeal membrane oxygenation: a systematic review. J Intensive Care Med 32(5):312-319. https://doi. org/10.1177/0885066616656333

141. Ranucci M, Ballotta A, Kandil H, Isgrò G, Carlucci C, Baryshnikova E, Pistuddi V (2011) Bivalirudin-based versus conventional heparin anticoagulation for postcardiotomy extracorporeal membrane oxygenation. Crit Care 15(6):R275. https://doi. org/10.1186/cc10556

142. Hamzah M, Jarden AM, Ezetendu C, Stewart R (2020) Evaluation of bivalirudin as an alternative to heparin for systemic anticoagulation in pediatric extracorporeal membrane oxygenation. Pediatr Crit Care Med. https://doi.org/10.1097/pcc.0000000000 002384

143. Nagle EL, Dager WE, Duby JJ, Roberts AJ, Kenny LE, Murthy MS, Pretzlaff RK (2013) Bivalirudin in pediatric patients maintained on extracorporeal life support. Pediatr Crit Care Med 14(4):e182-e188. https://doi.org/10.1097/pcc.0b013e31827200b 6

144. Bembea MM, Annich G, Rycus P, Oldenburg G, Berkowitz I, Pronovost $P$ (2013) Variability in anticoagulation management of patients on extracorporeal membrane oxygenation. Pediatr Crit Care Med 14(2):e77-e84. https://doi.org/10.1097/pcc.0b013 e31827127e4
145. Pollak U (2018) Heparin-induced thrombocytopenia complicating extracorporeal membrane oxygenation support in pediatric patients: review of the literature and alternative anticoagulants. Perfusion 33(suppl 1):7-17. https://doi.org/10.1177/0267659118 766723

146. Kawada T, Kitagawa H, Hoson M, Okada Y, Shiomura J (2000) Clinical application of argatroban as an alternative anticoagulant for extracorporeal circulation. Hematol Oncol Clin North Am 14(2):445-457. https://doi.org/10.1016/S0889-8588(05)70144-1

147. Padhya DP, Prutsky GJ, Nemergut ME, Schears GS, Flick RP, Farah W, Wang Z, Prokop LJ, Murad MH, Alsawas M (2019) Routine laboratory measures of heparin anticoagulation for children on extracorporeal membrane oxygenation: systematic review and meta-analysis. Thromb Res 179:132-139. https://doi. org/10.1016/j.thromres.2019.05.006

148. Trahanas JM, Kolobow MA, Hardy MA, Berra L, Zapol WM, Bartlett RH (2015) "Treating Lungs"- the scientific contributions of Dr. ASAIO J, Theodor Kolobow. https://doi.org/10.1097/ mat.0000000000000323

149. Maratta C, Potera RM, Van Leeuwen G, Castillo Moya A, Raman L, Annich GM, Brogan TV, Davidson M, Maclaren G, Peek G (2020) Extracorporeal Life Support Organization (ELSO): 2020 Pediatric Respiratory ELSO Guideline. ASAIO J. https://doi. org/10.1097/mat.0000000000001223

150. Raake J, Johnson B, Seger B, Manning PB, Eghtesady P, Boesch P, Rutter M, Woodard A, Chima RS (2011) Extracorporeal membrane oxygenation, extubation, and lung-recruitment maneuvers as rescue therapy in a patient with tracheal dehiscence following slide tracheoplasty. Respir Care 56(8):1198-1202. https://doi. org/10.4187/respcare.00948

151. Higashida A, Hoashi T, Kagisaki K, Shimada M, Takahashi Y, Hayashi T, Ichikawa H (2015) Efficacy of "Awake ECMO" for critical respiratory failure after pediatric open-heart surgery. $\mathrm{J}$ Artif Org. https://doi.org/10.1007/s10047-015-0876-3

152. Turner DA, Cheifetz IM, Rehder KJ, Williford WL, Bonadonna D, Banuelos SJ, Peterson-Carmichael S, Lin SS, Davis RD, Zaas D (2011) Active rehabilitation and physical therapy during extracorporeal membrane oxygenation while awaiting lung transplantation-a practical approach. Crit Care Med. https://doi. org/10.1097/ccm.0b013e3182282bbe

153. Schmidt F, Jack T, Sasse M, Kaussen T, Bertram H, Horke A, Seidemann K, Beerbaum P, Koeditz H (2015) "Awake venoarterial extracorporeal membrane oxygenation" in pediatric cardiogenic shock: a single-center experience. Pediatr Cardiol 36(8):1647-1656. https://doi.org/10.1007/s00246-015-1211-8

154. Anton-Martin P, Thompson MT, Sheeran PD, Fischer AC, Taylor D, Thomas JA (2014) Extubation during pediatric extracorporeal membrane oxygenation. Pediatr Crit Care Med 15(9):861-869. https://doi.org/10.1097/pcc.0000000000000235

155. Costa J, Dirnberger DR, Froehlich CD, Beaty CD, Priest MA, Ogino MT (2020) Awake neonatal extracorporeal membrane oxygenation. ASAIO J 66(5):e70-e73. https://doi.org/10.1097/ mat.0000000000001029

156. Collar RM, Taylor JC, Hogikyan ND, Tutuo N, Ohye RG, Green GE (2010) Awake extracorporeal membrane oxygenation for management of critical distal tracheal obstruction. Otolaryngol Head Neck Surg 142(4):618-620. https://doi.org/10.1016/j.otohn s.2009.10.031

157. Wickiser JE, Thompson M, Leavey PJ, Quinn CT, Garcia NM, Aquino VM (2007) Extracorporeal membrane oxygenation (ECMO) initiation without intubation in two children with mediastinal malignancy. Pediatr Blood Cancer 49(5):751-754. https ://doi.org/10.1002/pbc.20741

158. Hayes D, Galantowicz M, Preston TJ, Lloyd EA, Tobias JD, McConnell PI (2014) Tracheostomy in adolescent patients bridged to lung transplantation with ambulatory venovenous 
extracorporeal membrane oxygenation. J Artif Org 17(1):103105. https://doi.org/10.1007/s10047-013-0738-9

159. Nelson-Mcmillan K, Vricella LA, Stewart FD, Young J, Shah AS, Hibino N, Coulson JD (2020) Recovery from total acute lung failure after 20 months of extracorporeal life support. ASAIO J 66(1):e11-e14. https://doi.org/10.1097/mat.0000000000000990

160. Posluszny J, Rycus PT, Bartlett RH, Engoren M, Haft JW, Lynch WR, Park PK, Raghavendran K, Napolitano LM (2016) Outcome of adult respiratory failure patients receiving prolonged ( $\geq 14$ days) ECMO. Ann Surg 263(3):573-581. https://doi. org/10.1097/sla.0000000000001176

161. Brogan TV, Zabrocki L, Thiagarajan RR, Rycus PT, Bratton SL (2012) Prolonged extracorporeal membrane oxygenation for children with respiratory failure. Pediatr Crit Care Med 13(4):e249e254. https://doi.org/10.1097/pcc.0b013e31824176f4

162. Gupta P, McDonald R, Chipman CW, Stroud M, Gossett JM, Imamura M, Bhutta AT (2012) 20-Year experience of prolonged extracorporeal membrane oxygenation in critically ill children with cardiac or pulmonary failure. Ann Thorac Surg 93(5):15841590. https://doi.org/10.1016/j.athoracsur.2012.01.008

163. Green TP, Moler FW, Goodman DM (1995) Probability of survival after prolonged extracorporeal membrane oxygenation in pediatric patients with acute respiratory failure. Crit Care Med 23(6):1132-1139

164. Bailly DK, Reeder RW, Zabrocki LA, Hubbard AM, Wilkes J, Bratton SL, Thiagarajan RR (2017) Development and validation of a score to predict mortality in children undergoing extracorporeal membrane oxygenation for respiratory failure. Crit Care Med 45(1):e58-e66. https://doi.org/10.1097/ccm.0000000000 002019

165. Barbaro RP, Boonstra PS, Paden ML, Roberts LA, Annich GM, Bartlett RH, Moler FW, Davis MM (2016) Development and validation of the pediatric risk estimate score for children using extracorporeal respiratory support (Ped-RESCUERS). Intensive Care Med 42(5):879-888. https://doi.org/10.1007/s0013 4-016-4285-8

166. Barbaro RP, Bartlett RH, Chapman RL, Paden ML, Roberts LA, Gebremariam A, Annich GM, Davis MM (2016) Development and validation of the neonatal risk estimate score for children using extracorporeal respiratory support. J Pediatr 173:56-61. e53. https://doi.org/10.1016/j.jpeds.2016.02.057

167. Anton-Martin P, Papacostas M, Lee E, Nakonezny PA, Green ML (2016) Underweight status is an independent predictor of in-hospital mortality in pediatric patients on extracorporeal membrane oxygenation. J Parenter Enter Nutr. https://doi. org/10.1177/0148607116673185

168. Pettignano R, Heard M, Davis R, Labuz M, Hart M (1998) Total enteral nutrition versus total parenteral nutrition during pediatric extracorporeal membrane oxygenation. Crit Care Med 26(2):358-363. https://doi.org/10.1097/00003246-19980 2000-00041

169. Desmarais TJ, Yan Y, Keller MS, Vogel AM (2015) Enteral nutrition in neonatal and pediatric extracorporeal life support: a survey of current practice. J Pediatr Surg 50(1):60-63. https:// doi.org/10.1016/j.jpedsurg.2014.10.030

170. Jaksic T, Hull MA, Modi BP, Ching YA, George D, CompherParenteral ASF, Directors ENBo C (2010) ASPEN clinical guidelines: nutrition support of neonates supported with extracorporeal membrane oxygenation. J Parenter Enter Nutr 34(3):247-253

171. Hanekamp MN, Spoel M, Sharman-Koendjbiharie I, Peters JWB, Albers MJIJ, Tibboel D (2005) Routine enteral nutrition in neonates on extracorporeal membrane oxygenation*. Pediatr Crit Care Med 6(3):275-279. https://doi.org/10.1097/01.pcc.00001 61620.86647 .72

172. Greathouse KC, Sakellaris KT, Tumin D, Katsnelson J, Tobias JD, Hayes D Jr, Yates AR (2018) Impact of early initiation of enteral nutrition on survival during pediatric extracorporeal membrane oxygenation. J Parenter Enter Nutr 42(1):205-211. https://doi.org/10.1002/jpen.1032

173. Armstrong LB, Ariagno K, Smallwood CD, Hong C, Arbuthnot M, Mehta NM (2018) Nutrition delivery during pediatric extracorporeal membrane oxygenation therapy. J Parenter Enter Nutr. https://doi.org/10.1002/jpen.1154

174. Cavarocchi N, Wallace S, Hong E, Tropea A, Byrne J, Pitcher $\mathrm{H}$, Hirose $\mathrm{H}$ (2015) A cost-reducing extracorporeal membrane oxygenation (ECMO) program model: a single institution experience. Perfusion 30(2):148-153. https://doi.org/10.1177/02676 59114534288

175. Macartney J, Davidson L, Hamilton L, Foreman C, Humpl T, Da Silva Z, Campbell C, Gruenwald C, Sutton P, Guerguerian AM (2013) Evaluation of alternate staffing models for patients supported with extracorporeal membrane oxygenation in paediatrics. Paper presented at the Critical Care Canada, Toronto, ON, Canada

176. Frischer JS, Stolar CJH, Hirschl RB (2020) Extracorporeal membrane oxygenation for neonatal respiratory failure. In: Puri P (ed) Pediatric surgery. Springer, Berlin, pp 817-826. doi:https://doi. org/10.1007/978-3-662-43588-5_58

Publisher's Note Springer Nature remains neutral with regard to jurisdictional claims in published maps and institutional affiliations. 